
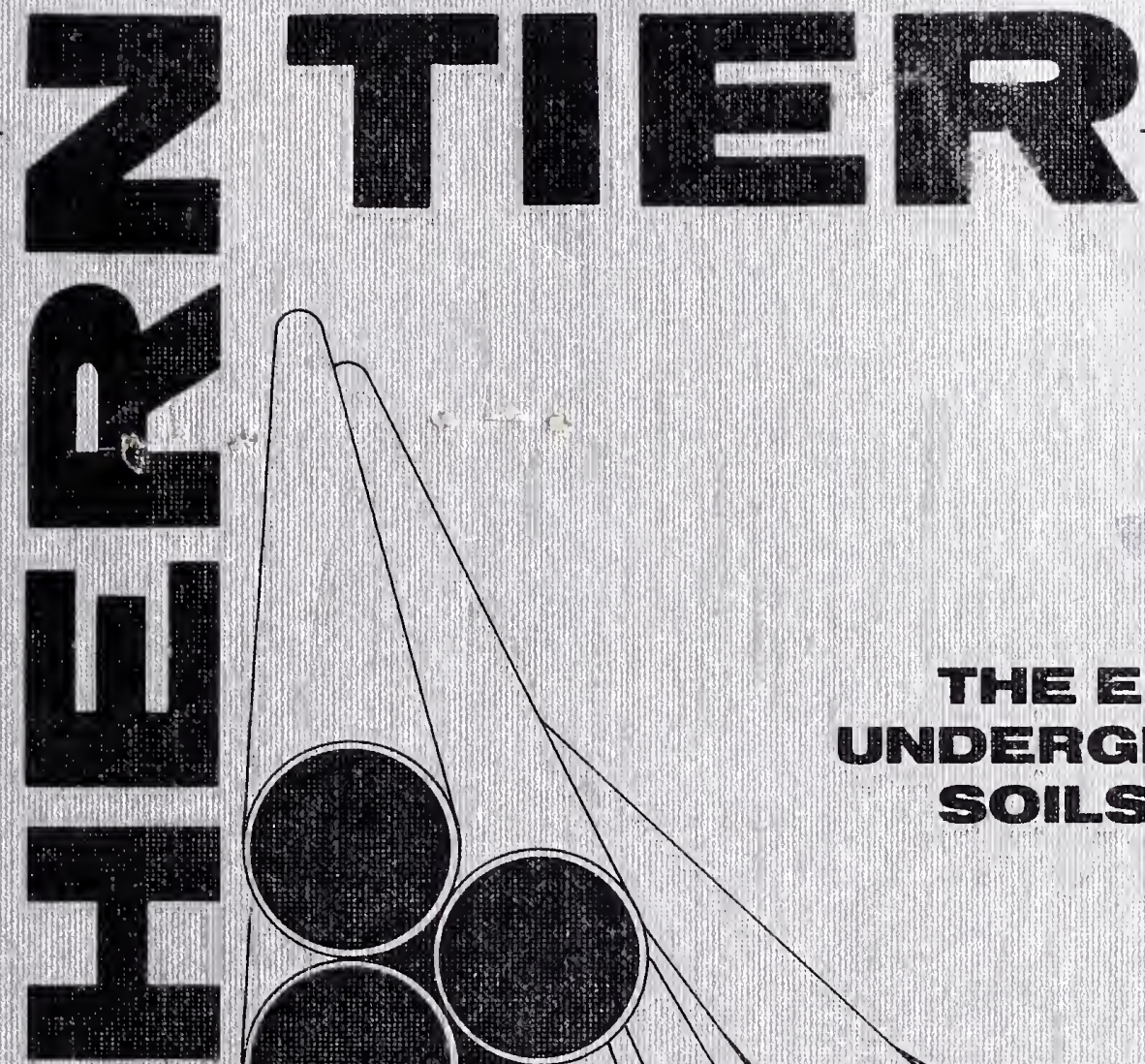

THE EFFECTS OF LAPCE UNDERGROUND PIPELINES ON SOLLS AND MEGETATION

Repore No.
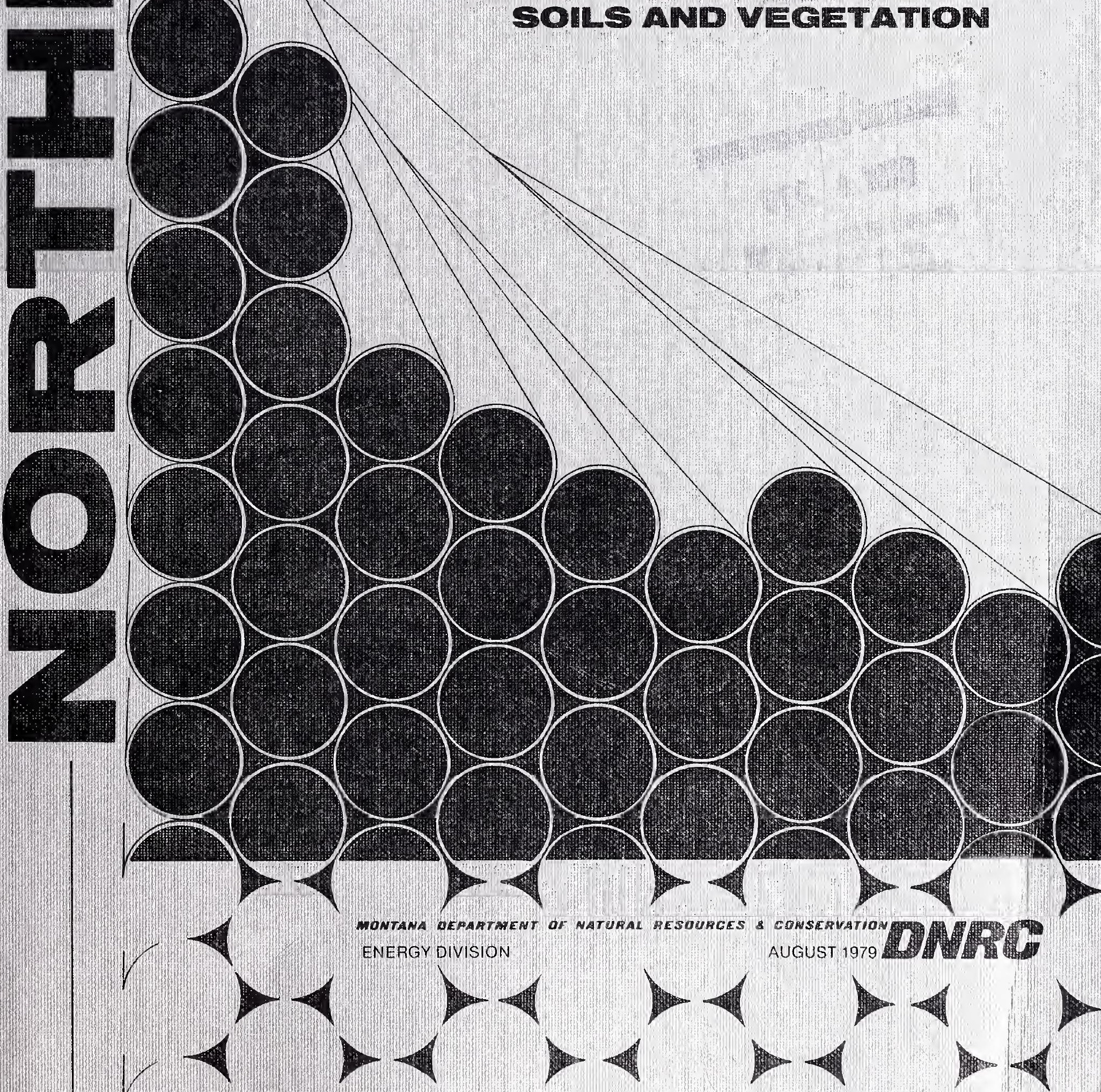


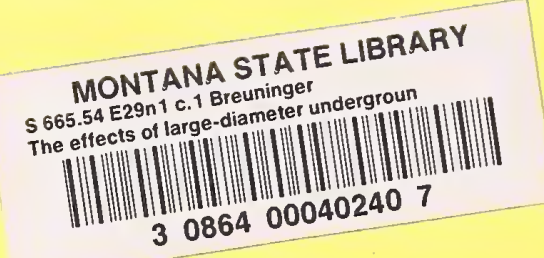

NORTHERN TIER REPORT NO. 1.

The Effects of Large Underground Pipelines on Soils and Vegetation

\section{ERRATA}

In the table of contents under "Effects of Pipeline System Construction," page iii, the following corrections should be made:

1) "Loss of Vegetation" should read "Disturbance of Vegetation."

2) "Fire Hazard" and "Growth of Weeds" should be reversed.

Under "Abbreviations," page vi, the correct spelling is fahrenheit.

In Chapter three, page 13, the following numbers should be corrected:

4.4 ha ( 11 acres) should read 490.7 ha (1212.12 acres).

36 ha (9 acres) should read 387.6 ha (957.58 acres).

2.6 ha (6.5 acres) should read 265.0 ha (654.55 acres).

On page 20, in the second paragraph under "Effects of 0il Spills," a rewording of the first sentence is suggested:

"The BLM (USDI 1979) estimated that 0.0022 spills per mile per year $\left(0.0014 \mathrm{spi} 11 \mathrm{~s}\right.$ per $\mathrm{km}$ per year) of more than $0.40 \mathrm{~m}^{3}$ ( 2.4 barrels) would occur along the proposed Northern Tier pipeline." 
Northern Tier Report No. 1

\title{
THE EFFECTS OF LARGE-DIAMETER UNDERGROUND CRUDE-OIL PIPELINES ON SOILS AND VEGETATION With Emphasis on the Proposed Northern Tier Pipelline in Montana
}

\author{
by \\ Ray Breuninger, Physical Sciences Coordinator \\ and \\ Larry Thompson, Liological Sciences Coordinator \\ Montana Departlient of Natural Resources and Conservation \\ in consultation with \\ 01 son-Elliott and Associates \\ Helena, Montana \\ Dave Janis, Project Manayer, Northern Tier Pipeline Study \\ Kathy Harison, Editor
}

Department of Natural Resources and Conservation

Energy Uivision

32 South Ewing

Helena, Montana 59601 



\section{CONTENTS}

Page

FIGURES •. . . . . . . . . . . . . . . . . . . . . $v$

TAELES . . . . . . . . . . . . . . . . . . . . . $v$

LIST OF ABBREVIATIONS . . . . . . . . . . . . . . . . . . vi

ACKNOWLEDGEMENTS . . . . . . . . . . . . . . . . . . v vi

INTRODUCTION . . . . . . . . . . . . . . . . . . . . 1

A GENERAL UESCRIPTIUN OF LARGE-DIAMETER

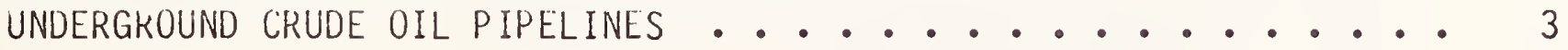

Summary of Activities . . . . . . . . . . . . . . 3

Pipeline Construction

Construction of Facilities Associated with a

Pipeline System

Pipeline Operation and Maintenance

Pipeline Abandonment

Actions and Facilities That would Pose the Greatest

Risk of Damage to Soils and Vegetation .......... 5

Right-of-Way clearing and Controlling Growth of

Vegetation Within a Permanent Right-of-Way

Facilities Associated With a Pipeline System

Hydrostatic Testing

0 il Spills

THE EFFECTS OF A PIPELINL SYSTEM ON SOILS AND VEGETATION • • • • • • • 13

Effects of Pipeline System Construction . . . . . . . . . 13

Loss of Vegetation

Soil Erosion

Sedimentation

Soil Compaction

Soil Horizon Mixing

Fire Hazard

Growth of Weeds

Effects of Hydrostatic Testing . . . . . . . . . . . 17

Effects of Operation and Maintenance . . . . . . . . . 18

Control of Vegetation Growth within a Permanent

Right-of-Way

Use of Herbicides

Use of Off-Road-Vehicles 
Page

Thermal Effects

Effects of $0 i 1$ Spills

Spread of a Spill

Movement of $\mathrm{Oil}$ into Soils

0il Toxicity to Plants

Extent of Vegetation Damage

Effects of Pipeline Abandonment . . . . . . . . . . . . 24

Summary of Effects of a Pipeline System

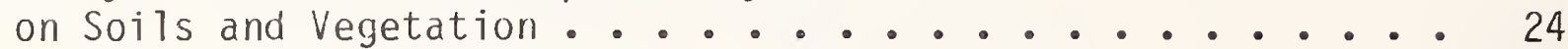

MITIGATING MEASURES . . . . . . . . . . . . . . . 27

Location of Pipeline and Associated Facilities . . . • • • . 27

Construction Practices . . . . . . . . . . . . . . 28

Timing of Construction Activities

Surveying and Staking

Access Roads

Material Sites

Clearing the Construction Right-of-Way

Trenching

Use of Motorized Vehicles

Fire Prevention and Control

Disposal of Debris

Monitoring Construction

Reclamation of a Construction Right-of-Way . . . . . . 32

Reclamation Plan

Timing of Reclamation

Reclarnation of Slopes

Reclamation Problem Areas

Revegetation

Monitoring Reclamation and Revegetation

Pipeline Uperation ... . . . . . . . . . . 35

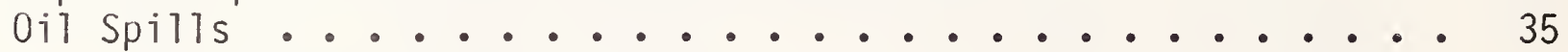

Oil Spill Contingency Plan

Control, Containment, and Cleanup of 0 il Spills

Reclamation Following a Major 0 il Spill ...........

Reclamation Practices

ivonitoring Reclamation

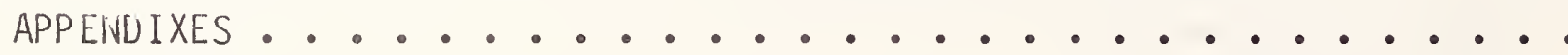

A. Methods of Identifying Areas of High

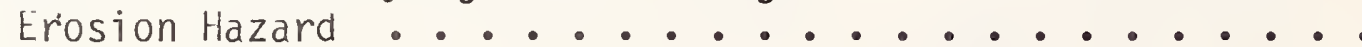

E. Methods of Identifying Areas of High

Vegetation Impact Risk ................. 45

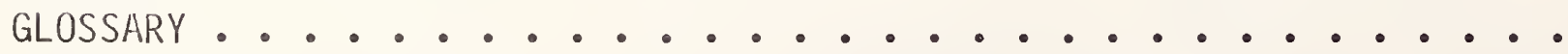

Literature Cited . . . . . . . . . . . . . . . . . . . 


\section{FIGURES}

Page

FIGURE 1 Temporary and Permanent Pipeline Easements and Rights-of-way

FIGURE '2

Typical Features of a Construction Right-of-way for a Large-Diameter Underground Pipeline . . . . . . . . 7

FIGURE 3 Probable Time Required to Restore

Productivity of Cropland Following

Uil Spills of Different Volumes . . . . 25

\section{TABLES}

Table 1

Plants Recommended for Use in Reclaiming

Forested 0il Spill Areas ........

Table 2

Erosion Potential of Various Parent

Miaterial Common in Montana ........ 


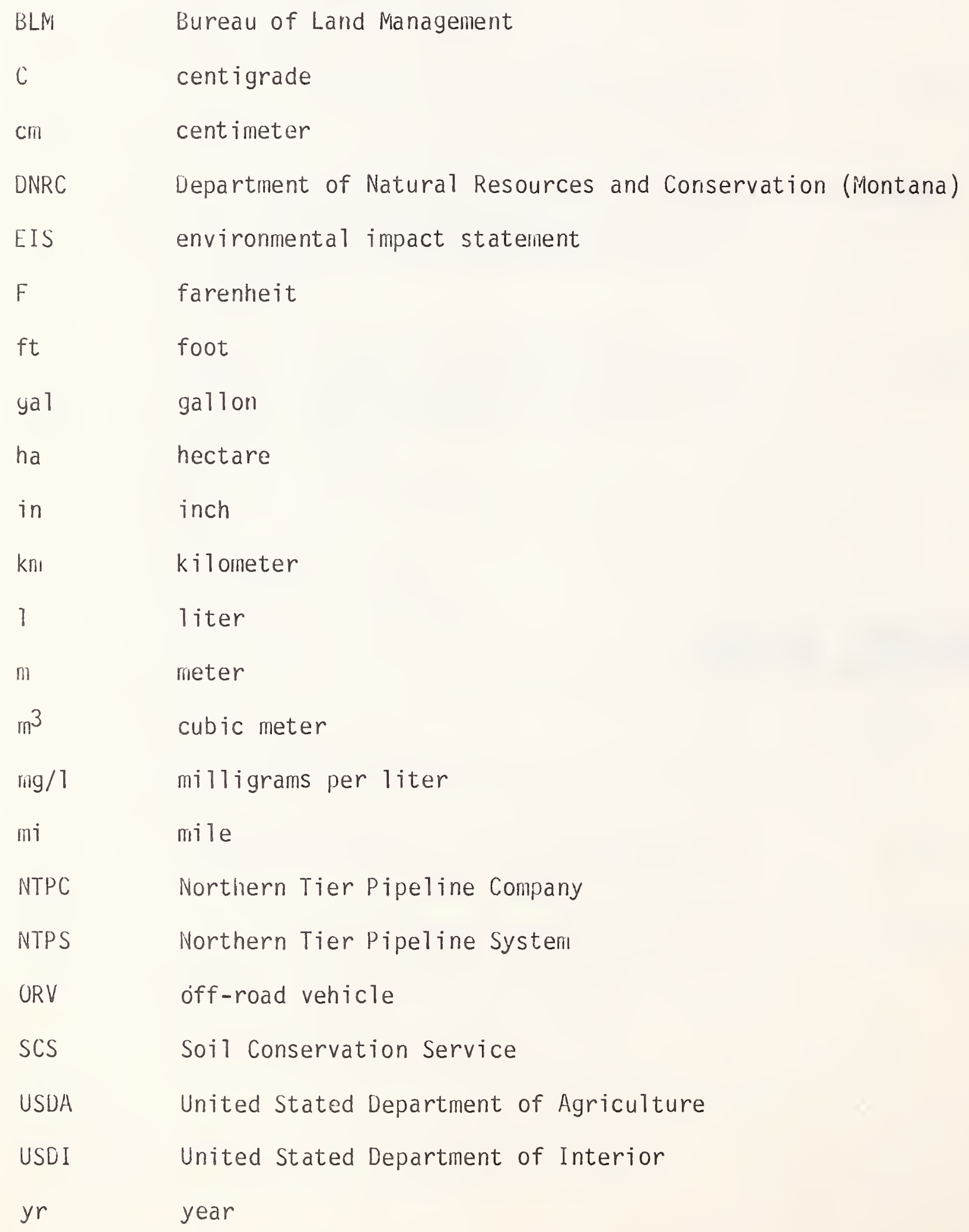




\section{ACKNOWLEDGEMENTS}

Northern Tier Pipeline Company funded studies of the potential impacts of the proposed Northern Tier Pipeline on soils and vegetation in Montana. Soils information was gathered by Adrienne Bonnet, and vegetation information by Dave McAllister, Joe Elliott, and Gerry Woore, all of 01 son-Elliott and Associates, consultant to the Montana Department of Natural Resources and Conservation (DNRC).

This report was prepared by Ray Breuninger and Larry Thompson, DNRC Energy Division, in consultation with 01son-Elliott and Associates. The report was edited by Kathy Hanson. Jack Fischer, USDA Forest Service, Lolo National Forest, provided a technical review of the vegetation information, and Gienn Smith, DNRC Water Resources Division, reviewed the soils information. Tom Wing, a private engineering consultant, and Jack Crank, of Gulf Interstate Engineering Company, provided information on crude-oil pipeline systern design and construction.

Others from DNRC who assisted in the report's preparation include: Lee Shelton, who made metric conversions and compiled the list of abbreviations, glossary, and literature citations; Pam Goddard and Denise Thompson, who typed the manuscript; June Virag and Gordon Taylor, who prepared the illustrations; and D. C. Howard, who designed the cover of the report. Special thanks go to Dave Lambert for his editorial guidance and to Gary Wolf for his assistance in preparing the report for publication. 
Digitized by the Internet Archive in 2016

https://archive.org/details/effectsoflargedi1979breu 


\section{CHAPTER ONE}

\section{INTRODUCTION}

The following analysis of the effects of a large-diameter, underground pipeline on soils and vegetation supplements the state's Draft EIS on the Proposed Northern Tier Pipeline System, prepared by the Montana Department of Natural Resources and Conservation (DNRC). The Northern Tier Pipeline Company (NTPC) has proposed a 102- to 107-cm-diameter (40- to 42-in-diameter) underground pipeline system to transport crude $0 i 1$ from a tanker port at Port Angeles, Washington, to Clearbrook, Minnesota, traversing approximately $1014 \mathrm{~km}$ ( $630 \mathrm{mi}$ ) of Montana en route.

The state's draft EIS discusses the impacts of Northern Tier's proposed route and alternative routes. The U.S. Bureau of Land Management (BLM) has also prepared a draft EIS on the proposed project (USDI 1979).

This report (1) gives a general description of large-diameter, underground, crude-0il pipelines (such as the proposed Northern Tier Pipeline System, or NTPS), (2) discusses the effects on soils and vegetation from construction, operation and maintenance, and abandonment of such a pipeline, and (3) identifies ways in which adverse effects on these two resources could be avoided or prevented. While the report emphasizes effects on Montana soils and vegetation, the information is generally applicable to study of the impacts a large, underground pipeline would have in other parts of the country where soils and vegetation are similar to those in Montana.

This report is one in a series of six reports prepared in conjunction with the state's draft EIS. The series consists of the following reports:

Report 1 The Effects of Large-Diameter Underground Crude-0il Pipelines on Soils and Vegetation, with Emphasis on the Proposed Northern Tier Pipeline in Montana

Report 2 The Effects of Large-Diameter Underground Crude-0il Pipelines on Wildlife, with Emphasis on the Proposed Northern Tier Pipeline in Montana

Report 3 The Effects of Large-Diameter Underground Crude-0il Pipelines on Aquatic Life and Habitats, with Emphasis on the Proposed Northern Tier Pipeline in Montana

Report 4 Earthquake Hazard to the Proposed Northern Tier Pipeline in Montana

Report 5 The Effects of Large-Diameter Underground Crude-0il Pipelines on Land Use, with Emphasis on the Proposed Northern Tier Pipeline in Montana 
Report 6 Social and Economic Impacts of the Proposed Northern Tier Pipeline in Montana

The reports are available on request from the Montana Department of Natural Resources and Conservation, Energy Division, 32 South Ewing, Helena, Montana 59601, (406) 449-3780. 


\section{CHAPTER TWO}

\section{A GENERAL DESGRHPTION OF LARGE UNDERGROUND CRUDE-OIL PIPELINES}

The following is a summary of the activities typically required to construct, operate and maintain, and aiandon a large-diameter, underground, crude-0il pipeline system. The effects of these activities are then discussed in the chapter of this report titlea "The Effects of a Pipeline System on Soils and Veyetation." More detailed discussions of pipeline system design and techniques of constructing, operating, and maintaining a pipeline are in chapters two ("Description and Justification of the Project as Proposed by NTPC") and five ("Engineering and Geotechnical Concerns") of DNRC's draft EIS.

\section{SUMMARY OF ACTIVITIES}

PIPELINE CONSTRUCTION

The construction of a large-diameter pipeline system would involve the following activities:

1) Making flights over the pipeline route prior to construction

2) Surveying and staking the centerline

3) Clearing vegetation from the construction right-of-way

4) Excavating the pipeline trench

5) Transporting pipe to the trerich, welding pipe sections, placing them on skids, and wrapping pipe with a protective cover (pipe staging)

6) Laying the pipe and backfilling

7) Constructing crossings where the pipeline intersects rivers, streams, canals, roads, utility lines, and other pipelines

8) Testing the soundness of the pipe (hydrostatic testing)

9) Reclaiming sites disturbed by construction

CONSTRUCTION OF FACILITIES ASSOCIATED WITH A PIPELINE

Facility construction would involve:

1) Establishing work camps for construction personnel where existing housing could not accommodate an influx of workers 
2) Possibly, constructing access roads to the pipeline and associated facilities 1

3) Building pump stations and delivery facilities

4) Installing high-voltage electrical transmission lines serving pump stations and delivery facilities, and low-voltage distribution lines serving valves

5) Establishing storage yards for pipe and construction materials

6) Excavating material sites (such as gravel pits)

\section{PIPELINE OPERATION AND MIAINTENANCE}

The following maintenance activities would take place during operation of a pipeline system:

1) Controlling growth of vegetation within the pernanent right-of-way

2) Maintaining pump stations, delivery facilities, and powerlines

3) Possibly, maintaining access roads to the pipeline, pump stations, and delivery facilities

4) Niaking survey fights over the right-of-way

5) Controlling, containing, and cleaning up oil spills arid reclaiming spill areas

\section{PIPELINE ABANDONMENT}

The following activities would occur after completion of pipeline operation:

1) Flushing oil from the pipeline with water

2) Collecting and treating the water at wastewater treatment facilities, normally constructed at discharge sites

3) Possibly, removing pipe from the trench; this would involve many of the previously mentioned construction activities, including accommodating construction workers, clearing the right-of-way, excavating the pipeline trench, and reclaiming disturbed areas

1For this report, access roads are defined as any road (including a spur road, right-of-way road, and construction traffic and passing lanes) that would be needed to reach a pipeline corridor or an existing road. ATthough NTPC has no plans to construct new access roads to its pipeline, new roads might be necessary with any of the alternative NTPS routes or the route of any other pipeline system that might be proposed through Montana. 
ACTIONS AND FACILITIES THAT WOULU POSE THE GREATEST RISK OF DAMAGE TO SOILS AND VEGETATION

Of the above, right-of-way clearing, controlling growth of vegetation within a permanent right-of-way, facilities associated with a pipeline, hydrostatic testing, and oil spills could cause the most damage to soils and vegetation; thus, they are described in more detail below.

RIGHT-OF-WAY CLEARING AND CONTROLLING GROWTH OF VEGETATION WITHIN A PERMANENT RIGHT-OF-WAY

The extent of damage to vegetation and soils from a pipeline system would depend largely on the alrount of land cleared for construction and the amount of land on which vegetation growth were controlled during pipeline operation.

Generally, more land would be required for pipeline construction than pipeline operation and maintenance; thus, a temporary easellent for construction usually would be wider than a permanent easement for operation and maintenance. In addition, the amount of land actually used to construct a pipeline could be less than the construction easement, and the land used for operation and maintenance could be less than the perinanent easement.

In this report, the strip of land actually used to construct a pipelirie is referred to as the construction right-of-way; the strip used for operation and maintenance is referred to as the permanent right-of-way. Figure 1 illustrates the differences between the construction and operation easements, and between the construction and permanent rights-of-way.

FIGURE 1. Construction and permanent pipeline easements rights-of-way.

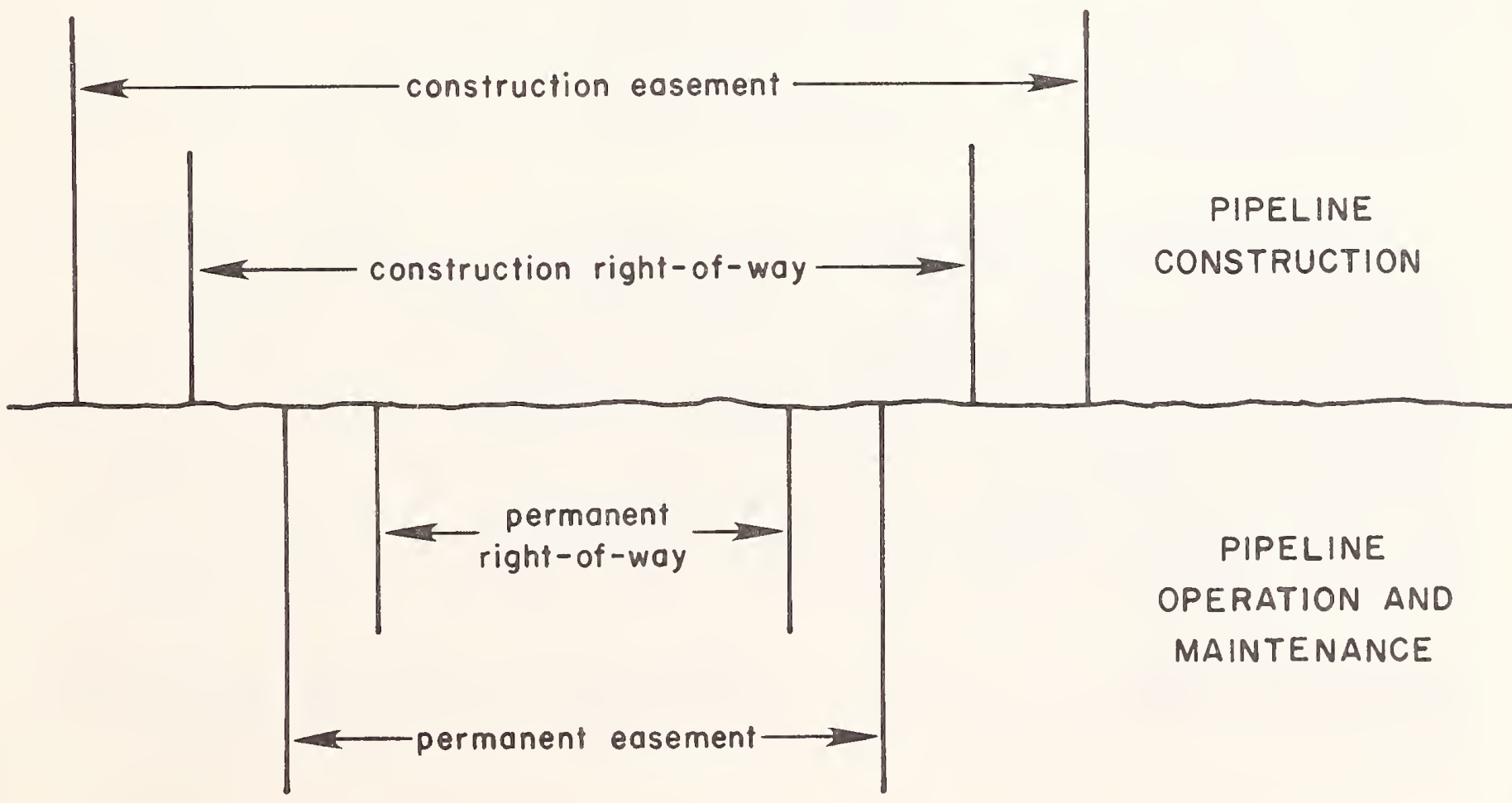


Amount of Land Cleared for a Construction Right-of-Way

The width of a construction right-of-way would vary, depending on the amount of land required for cut-and-fill slopes, pipeline trenching, spoils storage, pipe staging, and movement of construction equipment. Figure 2 shows the typical features of a construction right-of-way for a largediameter, underground pipeline. NTPC has proposed a 27-m-wide (90-ft-wide) construction right-of-way for most of the length of the pipeline, and a wider right-of-way at sites such as river crossings and on steep slopes, where construction would be difficult. The amount of additional land that would be required at difficult sites would be determined during centerline selection.

Cut-and-Fill Slopes. The amount of land required for cut-and-fill slopes would depend on the steepness of the terrain. For pipeline construction to take place efficiently (i.e. quickly and with ease of movement of machinery), a level construction pad would be required. On flat Tand, no grading would be required to construct a level pad; thus, no land outside the construction pad would need to be disturbed. But on sideslopes, where it would be necessary to cut and fill to construct a level working pad, more land would have to be disturbed.

Pipeline Trenching. The width of a pipe trench would vary, depending on the type of material excavated. For example, in rock and in tight silt or clay soils, where vertical walls could be dug, the trench for a 107-cmdiameter (42-in-diameter) pipe would be about $1.5 \mathrm{~m}(5 \mathrm{ft}$ ) wide. In gravel and other loose material, where walls would have to be excavated at an angle, the top of the trench could be as wide as $3 \mathrm{~m}$ (10 ft).

Spoils Storage. If topsoil and subsoil removed during trenching were stored in separate piles, abcut $9 \mathrm{~m}$ (30 ft) would be required for storage; this width would include a $0.6 \mathrm{~m}$ ( $2 \mathrm{ft}$ ) buffer strip between the piles to prevent mixing of topsoil, subsoi 1 , and grade debris. If the different spoils were piled on top of one another, about 6 to $7.6 \mathrm{~m}$ (20 to $25 \mathrm{ft}$ ) would be required for storage. It would also be possible to store spoils off the construction site; while this would reduce the amount of land required for construction, it would necessitate disturbing 1 and outside the construction area.

Pipe Staging. A strip about 2.4 to $2.7 \mathrm{~m}$ (8 to $9 \mathrm{ft}$ ) wide adjacent to the pipe trench would be required for pipe staging, which would involve positioning pipe sections parallel to the trench, welding the sections, placing the sections on skids adjacent to the trench, $x$-ray inspecting the welds, and wrapping the pipe with a protective cover. A $2.4 \mathrm{~m}$ (8 ft) staging area would also allow a 0.3 to $0.6 \mathrm{~m}$ (1 to $2 \mathrm{ft}$ ) buffer at the outside edge of the strip. In areas such as narrow canyons, the amount of 1 and required for staging could be reduced by welding pipe sections off the construction site, then dragging them to the right-of-way and making tie-in-welds; however, this would be practical only along short segments of the pipeline.

Traffic Lanes. The width of the construction right-of-way would al so depend on the number and widths of traffic lanes for construction equipment. For optimum construction ease and speed, it would be desirable to have a 

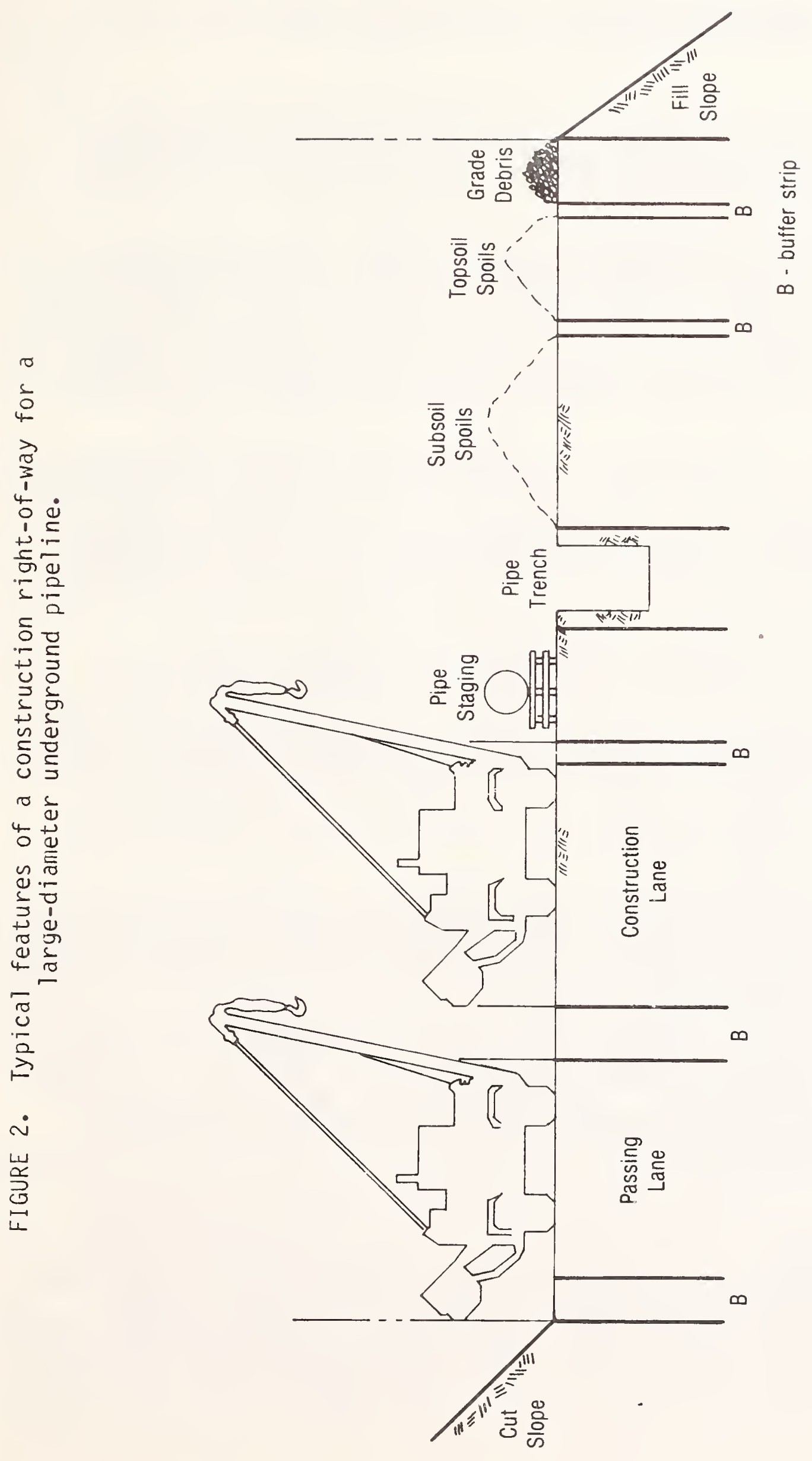
construction lane adjacent to the pipe staging area and a passing lane adjacent to the construction lane.

A minimum of $5.5 \mathrm{~m}$ (18 ft) would be required for a construction lane, which would be used by machinery hauling, welding, coating, and laying pipe. A lane of this width would accommodate the largest piece of construction machinery usually used--the sideboom tractor, which is $5.5 \mathrm{~m}$ (18 ft) wide with sidebooms extended.

With a 3.6-m-wide (12-ft-wide) passing lane (a lane the width of a sideboom tractor with the sideboom retracted) immediately adjacent to the construction lane, tractors could squeeze by one another, but passing would be easier if there were a 0.6 to $1.2 \mathrm{~m}$ ( 2 to $4 \mathrm{ft}$ ) buffer strip between the 1anes. In steep, forested areas, movement would be easier with a second buffer strip about $0.9 \mathrm{~m}(3 \mathrm{ft})$ wide on the outside margin of the passing lane, but the strip would not be necessary on cut-and-fill slopes.

By constructing access roads to the construction lane at frequent intervals, logging or county roads outside the right-of-way could serve as a passing lane. However, a passing lane outside the right-of-way would not be as convenient or allow as rapid construction as would one within the right-of-way. Also, construction traffic on logging or county roads could interfere with other traffic.

Construction could take place without a passing lane, but in the absence of a passing lane, only one construction activity could take place at a time, and the operation would be greatly slowed. Additional disadvantages of single-file operation would be: (1) the need to construct access roads at frequent intervals to minimize the length of the segment under construction, (2) damage to vegetation and soils outside the right-of-way if equipment left the construction lane, and (3) a delay in construction if equipment broke down.

An alternative more efficient than single-file operation but less efficient than a passing lane would be the establishment of frequent pullouts along the construction lane; this would allow passing at certain points along a construction segment.

Feasibility of Using Rights-of-way of Different Widths. As the preceding discussion indicates, considerable latitude is possible in the width of a construction right-of-way. Wider widths are preferable in terms of ease of construction, while narrower widths result in less disturbance of 1 and.

In all terrain, a right-of-way $27 \mathrm{~m}$ (90 ft) wide would allow ample room for an equipment passing lane and for storage of segregated topsoil and subsoil. In flat terrain, it would be possible to use a 23-m (75-ft) rightof-way and still have room for a passing lane and segregation of spoils. Use of a right-of-way narrower than $27 \mathrm{~m}$ (90 ft) would slow construction and make it more difficult because there would less room for movement of equipment. 
If the passing lane were eliminated, the right-of-way could be reduced to $19 \mathrm{~m}(65 \mathrm{ft})$; a right-of-way of this width could accommodate storage of segregated spoils on flat land, but might not permit segregation on steep terrain.

If both the passing lane and topsoil segregation were eliminated, it would be possible to confine construction to a 16-m (54-ft) right-of-way-the narrowest right-of-way that would allow conventional construction techniques to be used. Any right-of-way narrower than $16 \mathrm{~m}$ (54 ft) would require use of special equipment and construction techniques (such as storing spoils and welding pipe off the construction site) and would make construction more expensive than it would be on wider rights-of-way. (The above figures do not include land outside the graded construction pad that would be required to cut and fill slopes on steep terrain, nor do they include the additional land that would be required to construct river crossings.)

Amount of Land on which Vegetation Growth is Controlled for Pipeline Operation

Growth of vegetation within a permanent pipeline right-of-way would be controlled for the life of a project to:

1) Allow visibility of the land above the pipe from the air so that oil spills, leaks, pipeline damage, or hazards to the pipeline could be detected

2) Permit rapid movement of equipment to all points along a pipeline for maintenance, on-the-ground inspection, and emergencies

3) Prevent possible damage to the pipe from tree roots

NTPC had proposed a 23-m-wide (75-ft-wide) permanent easement and right-of-way on state and private land and a 16-m-wide (54-ft-wide) permanent easement and right-of-way on federal 1and. (The latter width is the maximum allowed by federal law on federal land without special approval from the Secretary of Interior.) However, the amount of land actually cleared for a permanent right-of-way could be less than the amount of land on which clearing would be allowed by the permanent easement, depending on local vegetation cover, land use, and slope, which would influence accessibility.

The pattern of management on many permanent rights-of-way for pipelines and facilities such as powerlines has been: (1) mechanical removal of woody vegetation during construction, (2) seeding with grass during reclamation, and (3) repeatedly spraying regrowth with an herbicide.

DNRC has determined that along most portions of a pipeline, a strip 3 m (10 ft) wide directly above a pipeline must be kept cleared of trees and shrubs. However, trees or shrubs could be planted above a pipeline for short distances if they would not reduce visibility for aerial surveillance. In forested areas, an additional $6 \mathrm{~m}(20 \mathrm{ft})$ would be maintained free of timber to serve as an access road. Timber and shrubs could be allowed to reestablish on the remainder of the right-of-way in forested lands, although 
some regrowth might have to be cleared again if an emergency required use of heavy equipment (for example, to reexcavate pipe).

A cleared strip as narrow as $9 \mathrm{~m}$ (30 ft) might be adequate for maintenance and emergencies, but a 15 to $23 \mathrm{~m}$ (50 to $75 \mathrm{ft}$ ) permanent easement would be desirable (especially on private land) because the pipeline company would have the legal right to clear and excavate in emergency situations and to prohibit encroachment onto land above the pipeline of structures that might pose a hazard to the line, or hinder maintenance or surveillance.

\section{FACILITIES ASSOCIATED WITH A PIPELINE SYSTEM}

\section{Access Roads}

To construct and operate a pipeline system, access to the pipeline and related facilities would be needed. In some areas, existing roads could be used; in other areas, new roads would be required. (See footnote on page 4 of this report.) Generally, access roads would be designed and constructed to accommodate the heaviest and widest equipment needed. Not all access roads would be permanently maintained. Those needed only for construction might not be maintained, although they could be used for surveillance during pipeline operation or for emergencies, such as oil spill cleanup. Others, such as roads to pump stations and delivery facilities and some roads to the pipeline, would be maintained for the life of a project.

The number and length of access roads required to construct and maintain a pipeline system would Targely depend on the location of the pipeline and associated facilities, and the type of construction operation employed.

\section{Other Facilities}

Pump stations, delivery facilities, storage yards, and work camps would also damage vegetation and soils. Pump stations for a large-diameter pipeline would require about 2 to 2.8 ha ( 5 to 7 acres) of 1 and; delivery facilities would require $24 \mathrm{ha}(60$ acres) or more. The size of work camps would vary according to the pipeline work schedule and the availability of existing housing. (NTPC has no plans to establish work camps.)

Pump stations and delivery facilities would require permanent use of land, but disturbance of soils and vegetation at work camps and storage yards would be temporary. Storage yards would probably be abandoned after construction, and restored to their former condition.

\section{HYDROSTATIC TESTING}

Federal law requires that the soundness of pipe be tested after it is laid in the trench by pressurizing pipe sections with water for a period of twenty-four hours at a pressure 1.25 times greater than the internal design pressure. Pipe would be tested in segments with water withdrawn from nearby water bodies; the length of a test segment would depend on availability of 
water, topography, the thickness of pipe walls, and other design factors. Test water would be discharged into nearby water bodies or onto the ground at the end of a test segnent, or transferred to another segment for testing.

A water leak or rupture in the pipe during hydrostatic testing would indicate where pipe was faulty or improperly constructed. This would enable the company to make repairs before operation began, thus avoiding oil spills. A company might also chouse to test pipe before laying it to avoid costs of reexcavation in the event of an unsuccessful test. However, even if an above-yround test were made, a second, underground test would be required.

\section{OIL SPILLS}

Minor oil spilis could result from leaking valves or gauges, oil losses at separators, or similar occurrences. Major spills could result from pipeline splits or ruptures caused by defective pipe, imperfect welds, pipe corrosion, landslides, vandalism, sabotage, excavation eyuipment hitting the pipe, river scour, earthquakes, and operational errors or accidents. ( $A$ minor spill would be less than $18 \mathrm{~m}^{3}--5,000 \mathrm{gal}$; a major spill would be $18 \mathrm{~m}^{3}--5,000$ gal--or more.)

Large spills should be automatically detected by instruments at pump stations that measured deviations in the pressure and volume of flow. Spills too small to be detected automatically could be discovered during aerial surveillance (which would take place about once every two weeks) or by observation by pipeline eriployees or the public. If a spill report were based on detection by instruments rather than direct observation, the exact location of the leak would not be known--all that would be known is that the leak was somewhere between two pump stations.

Personnel and equipment for containing and cleaning up a spill might not reach a spill until several days after its discovery. A leak under ice or frozen ground that was not large enough to be detected automatically could go undetected for a longer period of time than would a spill visible above ground. A more detailed discussion of spill risk is in chapter 5 ("Engineering and Geotechnical Concerns") of DNRC"s Draft EIS on the Proposed Northern Tier Pipeline System. 



\title{
CHAPTER TMREE
}

\section{THE EFFECTS OF A PUPELINE SYSTEM ON SOLLS AND MEGIRTIROR}

\author{
EFFECTS OF PIPELINE SYSTEM CONSTRUCTION
}

\section{DISTURBANCE OF VEGETATION}

The most widespread damage to soils and vegetation from a pipeline system would result from the clearing of a construction right-of-way the entire length of the pipeline. The extent of damage from clearing would depend on the width of the right-of-way. For example, a 161-kin-long (100-mi-long) construction spread with cleared rights-of-way $30 \mathrm{~m}$ (100 ft), $24 \mathrm{~m}$ (79 ft), or $16 \mathrm{~m}(54 \mathrm{ft})$ wide would result in clearing of 4.4 ha (11 acres), 3.6 ha (9 acres), or 2.6 ha $(6.5$ acres) respectively. In most places disturbed by pipeline construction, vegetation losses would be temporary if reclamation were successful. One exception would be forested areas, where regrowth of trees would generally be prevented above the pipeline for the life of a project.

Additional loss of vegetation would result from construction of pipeline facilities, such as roads; pump stations; delivery facilities; excavation sites (for sand, gravel, and other materials); electrical transmission lines to pump stations, delivery facilities, and valves; and storage yards for construction materials.

Roads built to facilitate pipeline construction and maintenance would result in loss of considerable amounts of vegetation. At least 24.3 ha (60 acres) would be cleared for each delivery station and about 2 ha ( 5 acres) for each pump station along a pipeline.

In most cases, construction of facilities associated with a pipeline would result in permanent vegetation losses. However, construction of material stockpile sites would result in loss of vegetation for only the duration of construction. The clearing of locally scarce vegetation types, such as riparian and wetland areas, would represent an especially important vegetation loss.

\section{Disturbance of Vegetation in Sensitive Areas}

Some environmentally sensitive areas disturbed by pipeline systern construction could be difficult to reclaim and revegetate. Such areas would include areas with a short growing season, soils with a high salt content or shrink-swell potential, very steep slopes, and badlands. In these areas, nets, chemical binders, and mulches are commonly ineffective in controlling erosion, or are effective for only a short time; thus, it would be important to monitor reclamation and revegetation efforts and take corrective actions where efforts failed in order to assure successful restoration of disturbed areas. 
Areas with a Short Growing Season. At high elevations, the short growing season limits reclamation potential. Native vegetation at high elevations is adapted to short growing seasons with extrene diurnal temperature variations. Plants begin growing early in the season, often before the snow is entirely gone. They flower and set seeds rapidly to assure successful reproduction before the severe frosts of late sumner and early fall. The shape of high elevation plants represents another adaptation; plants growing close to the ground are better able to withstand extreme weather conditions than are tall plants.

Successful high-elevation revegetation would require seeding of plants that could survive and regenerate under climatic extremes. Most plants that would be used to reclaim areas at lower elevations would not grow and reproduce successfully at elevations near timberline. Reclamation at high elevations would be most successful using seed from plants native to high elevations.

Soils at high elevations, particularly those above timberline, are susceptible to irreversible compaction; if ground cover is destroyed, they are generally' highly erodible.

Soils with a High Salt Content. Reclamation of areas with highly alkaline, saline, or alkaline-saline soils would be difficult. A high salt concentration is detrimental to plant yrowth because it breaks down soil structure, thus affecting moisture infiltration rates (Soiseth et a 1. 1974). Relatively large amounts of exchangeable sodium saturate the base exchange colloids in the soil and cause dispersion (Hanson and Whitman 1943). High salinity creates moisture stress for associated vegetation (Branson et al. 1970). Areas where soils and subsurface water commonly have high salt contents are often underldin by marine shales or strata high in salt content, such as the Bearpaw and Colorado shales. If the soil layer above such rock is $0.6 \mathrm{~m}(2 \mathrm{ft}$ ) deep or deeper, the salts may present few reclamation problems.

Soils with a High Shrink-Swell Potential. Soils with a high content of expandable clay often shrink and swell with fluctuations in soil moisture. Soil contraction and expansion can kill many fine-rooted plants (White and Lewis 1969). Hemmer et al. (1977) studied reclamation efforts on bentonitic soils (montmorillonite clay) in Valley County, Montana (near Glasgow), and found reclamation of land mined for bentonite has been difficult. In some places, problems in reclaiming highly bentonitic soils disturbed by a pipeline might be similar to problems experienced in reclaiming areas mined for bentonite.

Branson et al. (1966) experimented with several management practices (contour furrowing, fertilization, and seeding) on saline, dense-clay soils derived from the Bearpaw shales in Valley County. In addition to having a high shrink-swell potential because of their clay content, moisture infiltration into these soils is imhibited by the high salt concentrations. Branson et a1. found that the management practices they employed did not improve establishment of vegetation on the soils with the highest clay and salt contents. However, high shrink-swell clays are not always saline, and would not always pose revegetation problems. There are many areas where small grains are successfulty produced on dry or irrigated cropland with soils that shrink and swell. 
Very Steep Slopes. Steep slopes would be difficult to reclaim because of their susceptibility to erosion. The potential for erosion of topsoil and seeds would increase with increased slope.

Badlands. Badlands have steep, unstable slopes, high levels of erosion from wind and water, and relatively sparse vegetation. Brown (1971) found that badland plant communities are unique in their vegetative composition and microenvironmental requirements; the plant communities have distinct boundaries and individual communities are often restricted to relatively small areas. If a pipeline were built across badlands, revegetation would be hindered by the availability of seed; no single seed mixture could be used to revegetate the entire area.

\section{SOIL EROSION}

The loss of soil, particularly topsoil, by wind and water erosion is high where vegetative cover is removed, soil horizons are mixed, soil is compacted, slopes are steep or long, and in areas contaminated by an $0 i 1$ spill or leak. The most severe erosion caused by a pipeline would occur during construction of the pipeline and associated facilities, when large portions of the right-of-way and other construction sites would be devoid of vegetation. Access roads used during pipeline operation and maintenance could present erosion hazards for the life of a pipeline, but measures could be taken to control erosion.

The amount of soil lost to wind and water erosion from pipeline construction and maintenance would depend on the type of reclamation practices employed and the amount of time before a stable vegetative cover were reestablished. However, because no reclamation practice could completely control erosion, some erosion would be inevitable (USDI 1979).

Significant amounts of soil could be lost from wind erosion during winter months, particularly in eastern Montana. In addition, soil erodibility could be increased by oil spills. If spilled oil penetrated the soil, soil disaggregation and the dispersion of soil colloids would decrease soil cohesion and shear strength, thus increasing erodibility (Ellis and Adams 1961).

Erosion could damage plants by exposing their root structures, which would lead to plant dehydration. Plants could also be buried by sediment transported by wind or water. In addition, seeds (both native seeds and those introduced for reclamation purposes) could be carried away by wind or water.

\section{SEDIMENTATION}

The clearing of streambank vegetation, trenching in streams, and pipeline placement would increase stream sediment loads and deposition of sediments, in turn damaging aquatic plants. Unstable sediments shift rapidly according to variations in stream velocity, at times burying vegetation, at other times washing it out (Crabtree et a1. 1978). (The potential effects of pipelines on aquatic life and habitats are discussed in detail in Northern Tier Report No. 3.) Vegetation on land adjacent to the right-of-way could also be smothered by accumulations of dust. 
Heavy equipment operating along a pipeline would compact soils. According to Voorhees (1977), compaction may decrease pore volume by 10 percent in the upper $26 \mathrm{~cm}(10.2 \mathrm{in})$ of soil. Seventy percent of compaction may occur within the first five passes of equipment (Raghaven et al. 1977). A reduction in soil pore volume could reduce the moisture infiltration rate and the availability of moisture to plants, thus increasing runoff and erosion, and reducing soil moisture holding capacity.

According to Kulkarni and Savant (1977), plants in compacted soil have less efficient nutrient and water uptake because root diameter increases, and root length and the depth of root penetration decrease. However, compaction of very well drained soils may favor plant growth by reducing infiltration and permeability, thus increasing water retention.

Darnage to most soils from compaction could be corrected during reclamation, but in some soils, no reclamation technique could completely restore soil to its original condition.

SOIL HORIZON MIXING

Soil horizons would be mixed at all excavation sites for a pipeline and associated facilities; however, mixing of topsoil and subsoil could be prevented by storing the two types of soil separately. Storing the two separately would not eliminate mixing of one topsoil layer with another topsoil layer, or one subsoil layer with another, but it would help maintain soil productivity by keeping topsoil intact.

When horizons are mixed, changes in porosity, permeability, infiltration rates, and $\mathrm{pH}$ may affect plant growth and increase erosion potential. The mixing of horizons could increase soil fertility by bringing nutrients to the surface, but this could also make toxic salts available to plants. Rangeland soils are particularly susceptible to damage from horizon mixing because horizons have not already been plowed and mixed. In croplands, the upper soil horizons have been mixed by plowing. In both cropland and rangeland, the stockpiling and replacement of topsoil removed during trenching would be critical to successful revegetation of most areas.

\section{GROWTH OF WEEDS}

Successful revegetation of land disturbed by pipeline system construction could be inhibited by the growth of weeds. Many species of weeds would colonize a construction right-of-way; the extent of colonization would depend on the season in which construction took place, the duration of construction, the amount of time that elapsed between the end of construction and the begirning of revegetation, and the type of weeds in nearby plant comminities.

Probably, most weeds that would irivade a right-of-way would be annuals or biennials, such as pigweed (Chenopodiuin spp.), mullein (Verbascum thapsus), 
sunflower (Helianthus annus), and Russian thistle (Salsola kali). But perennials, such as Canadian thistle (Cirsium arvense), could spread to a right-of-way by way of rhizones or fraginented roots and eventualty become established. Perennial noxious weeds could be an especially serious problem if they were allowed to become established in or adjacent to cropland.

Growth of weeds within a pipeline right-of-way could be inhibited by spraying with herbicides. The use of herbicides is discussed on pages 18 and 19 of this report.

FIRE HAZARD

The potential for fires would increase with construction of a pipeline, particularly during the summer. If slash from clearing were not properly disposed of, combustible materials would accumulate. Fuel buildup, along with the use of reavy equipment, fuel spills, and an influx of construction workers would increase the probability of fire.

\section{EFFECTS OF HYUROSTATIC TESTING}

During hydrostatic testing, water would be discharged at the end of a test segment to depressurize the pipe section. As much as 32.5 million 1 (8.6 million gal) of water could be expelled froli a $32.2 \mathrm{~km}$ (20 mi) test section during depressurization or from a major rupture. Unsound welds between sections could also result in water losses.

Discharge water sornetimes contains residues toxic to plants (for example, oit and grease from inside the pipe). Water discharged from pump stations in Alaska contained a maximum $56.9 \mathrm{mg} / 7$ oil and grease and 24,820 $\mathrm{mg} / 1$ suspended solids (Hughes 1976); if water discharyed during hydrostatic testing of the NTPS or any other pipeline systern would be of similar quality, the extent of vegetation damage could be comparable to damage caused by a minor oil spill (a spill less than $18 \mathrm{~m}^{3}$, or 5,000 gal).

The degree of vegetation and soil damage from water expelled during hydrostatic testing would depend on the water velocity, the quantity expelled, and water quality. Valves at depressurizing points would reduce flow velocity, but if valves wert not used or were damaged, large quantities of water could be expelled at a high velocity, eroding soils and damaging vegetation in the discharge area; however, measures could be taken to control the erosion (for example, settliny ponds could be constructed at discharge sites). Water leaks during hydrotesting could also cause erosion in the immediate area of the leak. 
The permanentiy maintained pipeline right-of-way is usually narrower, at least by the width of a passing lane, than the right-of-way cleared for pipeline construction. Regrowth of trees and tall shrubs is prevented on a permanent right-of-way to allow access for maintenance and emergency use of equipment, provide visibility for aerial surveillance, and prevent damage to the pipeline from tree roots. Thus, where a right-of-way would cross forested areas, timber productivity would be lost for the life of the pipeTine project, a long-term impact. The impact on vegetation outside a permanent right-of-way would be short-term if efforts to restore the original plant cover and soil productivity were successfui.

\section{USE OF HERBICIDES}

Rights-of-way for powerlines, highways, railroads, and pipelines are often sprayed with herbicides to inhibit vegetation growth and control weeds. The use of herbicides to maintain rights-of-way could result in:

1) Removal of plant species beneficial to wildiife

2) Reduction of deep-rooting tree and shrub species that help stabilize soils

3) Aesthetic impacts from unsightly dead or dying vegetation and the unpleasant odor of herbicidal sprays and associated surfactants

4) Increased fire hazard from dead and dying vegetation

5) Damage to sensitive crops or trees adjacent to the right-of-way

6) Possible long-term effects on humans and other animals

The effect of herbicides on plant communities varies, depending on the plant species present and the type of herbicide used. In general, herbicides used for right-of-way maintenance reduce the growth of shrubs, trees, and broad-leaved vegetation but do not reduce growth of grasses, sedges, and ferns (which are relatively insensitive to phenoxy-type herbicides).

Payne (no date) treated sagebrush/grassland communities of the Beaverhead National Forest, Montana, with 2,4-D to determine the responses of forbs, grasses, and shrubs. Two years after spraying, forbs showed a 40 to 60 percent decrease in growth; growth of grasses and sedges increased because competing vegetation had been removed. Shrub species were largely eliminated on the sprayed plots, except for Chrysothamnus nauseosus and Rosa woodsii, whose growth increased.

Evans and Young (1977) used 2,4-D, Picloram, and Atrazine to control Bromus tectorum and Artemisia tridentata on a sagebrush/grassland community in Nevada. Application of the herbicides increased the yield of the perennial grasses Agropyron intermedium and Agropyron desertorum. 
Lyon and Mueggler (1968) treated shrub species in northern Idaho with 2,4-D and 2,4,5-T. Many of the species they treated occur in the forest habitat types of western Montana. They found that Ceanothus sanguineous was very sensitive and Acer glabrum and Salix scoulerian were less sensitive to herbicide sprays. (At present, $2,4,5-\bar{T}$ would not be used to control growth of vegetation in forested areas because the Environmental Protection Agency, EPA, has suspended its use in forests.)

Ryker (1970) tested shrubs and trees in northern Idaho, applying Picloram, Dicamba, and 2,4-D individually and in combination. The shrub species most resistant to herbicide treatment were Menziesia ferruginea, Acer glabrum, and Holodiscus discolor; the most sensitive species were Physocarpus malvaceous, Ceanothus sanguineus, and Salix spp. All of the coniferous trees exposed to the three herbicides died. Tree species tested were Picea engelmannii, Abies grandis, Pinus contorta, Pinus ponderosa, Pseudotsuga menziesii, Thuja plicata, and Pinus monticola.

Ryker (1966) treated shrubs in northern Idaho with 2,4-D, 2,4,5-T, and Tordon. Hie found the species most sensitive to the herbicides were Rosa spp., Ceanothus velutinus, Amelanchier alnifolia, and Spirea spp. Symphoricarpos spp., Acer glabrumi, and Vaccinium spp. were less sensitive to treatment.

Carvell (1976) reviewed the effects of using herbicides to maintain powerline rights-of-way. He concluded that phenoxy herbicides (such as 2,4-D and $2,4,5-T$ ) cause relatively litile damage to vegetation because they do not persist in the soil and, therefore, allow relatively rapid reinvasion of many plants. However, piclorari persists in soils and inhibits reinvasion of herbicide-sensitive species for many years after its application.

Chappell et al. (1976) discussed the use of chemicals to inhibit vegetation yrowth along rights-of-way. Sustar, MH-30, Ethrel, Silvex, and Amidthin were tested on grasses, forbs, and shrubs in Virginia. They concluded that some chemicals can reduce growth of undesirable woody or grassy vegetation without causing unsightly "brownouts" or permanently damaging desirable plant species. (EPA has also suspended use of Silvex.)

\section{USE OF OFF-ROAD VEHICLES}

Roads built to construct and maintain a pipeline would provide off-road vehicles (ORV'S) access to the pipeline corridor. Frequent or indiscriminate use by ORV's would darnage vegetation and impede revegetation. Several pro. blems would result from ORV travel and vegetation loss--formation of ruts, soil compaction, increased soil erosion and dust pollution, and alteration of natural drainage patterns.

\section{THERMAL EFFECTS}

The temperature of oil in a pipe would probably be near ground temperature along most of a pipeline route through Montana (USDI 1979). However, oil temperatures would rise near pump stations; with the proposed NTPS, a temperature of at least 21 degrees C (70 degrees F) could be expected near 
pump stations in some instances. Where the pipeline came within $0.9 \mathrm{~m}$ (3 $f t$ ) of the ground surface, temperatures would probably be warm enough to melt snow.

Because most plants in Montana have a phenological response to critical temperature or light conditions, an increase in soil temperature would cause vegetation to begin growing earlier in the year than normal, possibly increasing grazing and trampling by cattle and wildlife.

\section{EFFECTS OF OIL SPILLS}

0il spills could result from a number of events, including a malfunctioning pump station, pipeline leak, or an acrident during the refueling of vehicles or oil storage facilities. A spill would have an immediately damaging effect on soils and vegetation within the spill area. If a spill were to contaminate a terrestrial ecosystem, vegetation and soils would be severely daliaged, and soil productivity would be reduced for two to five years or longer.

The BLM (USUI 1979) estimated that 0.0022 spills of more than $.40 \mathrm{~m}^{3} / 1.6 \mathrm{~km}$ (2.4 barrels/mi) would occur each year along the proposed Northern Tier pipeline. According to this rough estinate, there would be approximately $28 \mathrm{spiils}$ of $.40 \mathrm{~m}^{3}$ (2.4 Darrels) or more along the $1014 \mathrm{~km}$ (630 mi) of the proposed NTPC in Montana in a period of twenty years. (The probability of oil spills is discussed more fully in chapter five, "Enyineering and Geotechnical Concerns," of the DNRC draft EIS.)

According to the NTPC (1978), the maximum volume that could be spilled from the proposed NTPS is $10,200 \mathrm{~m}^{3}$ (64,000 barrels)--the maximum volume between two valves. A spill of this size would be detected automatically by equipment at pump stations, and the valves closed. According to the BLM (USDI 1979), the minimum amount of spill that could be detected automatically is over $563 \mathrm{~m}^{3} /$ day $(3,540$ barrels/day). Reconnaisance flights over the pipe1 ine would probably be made every two weeks, so it is possible that oil could leak for a week or more before being detected; thus, if a spi 11 of $563 \mathrm{~m} / \mathrm{day}$ $\left(3,540\right.$ barrels/day) went undetected for seven days, $3,900 \mathrm{~m}^{3}$ (24,780 barrels) would be spilled.

An analysis of fifty-three oil spills in Alberta, Canada, indicated that a $2,100 \mathrm{~m}^{3}(13,200$ barrel) $0 i 1 \mathrm{spill}$ caused a $3.9 \mathrm{~cm}(1.6 \mathrm{in}) 0 i 1 \mathrm{film}$ to cover 5.5 ha (14 acres) (Mackay and Mohtadi 1975). If that amount of spilled oil were absorbed into an $20 \mathrm{~cm}(8 \mathrm{in})$ soil layer over bedrock, there would be 20 percent $0 i 7$ by volume in the soil. When Mackay and Mohtadi's estimates of contamination are applied to the above spill estimates, the following picture emerges: a spill of $10,200 \mathrm{~m}^{3}$ (64,000 barrels) would contaminate 27 ha (66 acres) and a spill of $3,900 \mathrm{~m}^{3}$ (24,780 barrels) would contaminate 10 ha (26 acres), assuming ground conditions similar to those found in Canada. 
The material used to fill a pipeline trench is generally more permeable than the soil removed during trenching. Eecause fill material offers little resistance to oil penetration, a spill would generally be confined to a pipeline trench. However, if a trench became saturated with oil, the oil would flow laterally across the ground surface; in permeable soil, some oil in the trench might also infiltrate directly into the soil.

The distance spilled oil would move over the ground would depend primarily on the physical and cremical properties of the oil, and the topography, soil permeability, and vegetative cover of the spill area. Of these factors, topography is the most important in determining the shape and areal extent of a spill. Mackay ard Mohtadi (1975) found that in rolling terrain the depth of a spill increases with increased oil loss, but the rate of lateral spread decreases with increased loss because the spill is confined to depressions. For example, a spill on level terrain would tend to be circular in shape. A spill on a slope would tend to be elongated, with a relatively short leading edge and little lateral movement. The distance oil would flow down a slope would depend primarily on the slope's steepness and the rate of leakage.

Spilled oil would continue to spread until it reached a natural depression, was absorbed into the soil, or was stopped by friction with ground cover. The type of vegetation in a spill area would affect the rate of oil flow and the distance oil would spread. For example, a spill on relatively barren ground would flow faster and spread farther than a spill on heavily vegetated ground. If oil spilled in an area with a thick layer of moss and shrub or tree cover, significant amounts of $0 i 1$ would be absorbed by the oryanic layer, and oil would adhere to trees, shrubs, and other vegetation. Studies by Mackay and Mohtadi (197b) indicate that a $0.3 \mathrm{~m}$ (1 ft) organic layer can hold about 3.81 (1 gal) of crude $0 i 1$ per $0.09 \mathrm{~m}^{2}\left(1 \mathrm{ft}^{2}\right)$ of subsurface.

Mackay and Mohtadi (1975) developed a method of predicting the rate of oil flow on an inclined surface considering factors such as oil density, flow width, oil filin thickness, oil viscosity, and slope steepness. For example, a spill of Prudoe Bay crude oil with a temperature of 38 degrees C (100 degrees F) flowing at a rate of 10,000 barrels/hr down a 5 -degree slope in a 60 -n-wide (200-ft-wide) stream would spread at a rate of about $0.9 \mathrm{~m} / \mathrm{sec}$ ( 3 $\mathrm{ft} / \mathrm{sec}$ ), or $3 \mathrm{kmil} / \mathrm{hr}(2 \mathrm{mi} / \mathrm{hr})$. The initial rate of flow would be reduced significantly by friction with vegetation and absorption by porous soils. Flow would also be slowed by cuol weather or by oil coring in contact with cooler ground, because oil would become more viscous.

The distance oil would spread over ice would depend largely on the rouginess and permeability of the ice and the viscosity of the oil. The U.S. Coast Guard has developed a method of predicting (based on these considerations) the size of the area of ice that would be covered by a spill. As an example, 1,600 $\mathrm{m}^{3}$ (10,000 barrels) of oil would spread into a circular spill with a radius slightly larger than .16 km (.01 mi). 0il spilled on snow probably would not flow as far as oil spilled on ground with no snow cover because snow retards the spread of $0 i 1$ by absorbing it and lowering its temperature. 
0il spills may affect soils by reducing infiltration; decreasing fertility and productivity; increasing inicrobial activity; altering $\mathrm{pH}$; decreasing aeration; increasing the potential for fire; changing soil color, temperature, and structure; reducing wettability; and polluting ground water. The significance of impacts from an oil spill would depend on its size, the depth to which oil penetrated soil, the type of oil spilled, soil texture, terrain, and the existing and potential use of the land.

On saturated soils, oil floats and forms ponds in surface depressions. The extent to which oil would form ponds would depend, in part, on soil wettability, infiltration capacity, the extent of soil disaggregation, and soil structure (Rowell 1977). An oil coating on soil particles reduces soil wettability and occupies space that might otherwise contain air or water.

In dry soil, oil penetrates the ground surface, infiltrates downward, and moves lateraliy. Uil penetration may create a bogay, barren area. Soils penetrated by oil to a depth of about $1.2 \mathrm{~m}(4 \mathrm{ft})$ are generally impermeable to rain. Generally, plant damage and problems in revegetating a spill area would result froin insufficient inoisture and air, although insufficient mutrients could also limit plant growth. Nitrogen supplements are necessary to reclaim soil contaminated with oil; however, with excessive amounts of nitrogen fertilizers, first and second year crops would have dangerously high nitrate concentrations.

Rowell (1977) found oil could increase or decrease soil pH; thus, oil spills could inhibit plant growth by creating alkaline or acidic soil conditions. Volatilization of some oil components could increase the potential for fire, which could kill soil microbes important to oil decomposition, soil aggregation, and plant growth. The burning of oil during spill cleanup could release toxic gasses into the environment and leave a tarry crust on the ground surface (Toogood et a 1. 1977). The formation of a crust could indirectly affect plant growth and survival by reducing soil aeration, impairing surface gas exchange, reducing water-holding capacity, causing intense microbial action leading to nitrogen deficiencies, and making toxic minerals available to plants. All of these effects could lead to a loss of vegetation.

$0 i 1$ that penetrated the soil could also inhibit plant reproduction by soaking through the seed coat, destroying the embryo, and preventing seed yermination. In mineral soils, germination appears to be adversely affected when oil content reaches 2 to 4 percent by soil weight.

\section{OIL TOXICITY TO PLANTS}

0ils vary in toxicity according to the composition of their carbon compounds. Of carbon compounds, paraffins are the least toxic, followed (according to increasing toxicity) by napthenes, olefins, and aromatics (Leonard and Harris 1952). Within each of these groups of compounds, those with small molecular weights appear to be more toxic than those with large molecular weights because they can penetrate a plant leaf more easily (Van 
Overbeek and blondeau 1954). Refined or weathered crude oil is believed to be less toxic than fresh crude oil because its molecular weight is low and its volatile components have been reduced (Rowell 1977).

A plant's sensitivity to oil depends largely on its anatomy. For example, plants with thick leaf surfaces or few stomata (such as the xerophyte Sedum) are generally resistant to oil penetration (Minshall and Helson 1949). Plants with broad leaves and abundant stomata are probably sensitive to damage from oil. (Most plants have this physiognomy.) Nelson and Smith (1968) found land plants more sensitive than algae to Torrey Canyon crude oil, possibly because the algae's mucilaginous covering prevented oil penetration.

When oil has penetrated the leaf surface, it moves into the space between cells (Minshall and Helson 1949) and damages the plasma membrane, resulting in loss of cellular fluids and darkening of the leaf (Currier 1951). Oil that penetrates the leaf surface reduces respiration (Rasmussen 1947) and photosynthesis (Minshall and Helson 1949).

$0 i 1$ also reduces plant transpiration rates. Riehl et al. (1958) ascribe this effect to oil coating the leaf surface. Plants growing close to the yround (for example, mosses and lichens) are often killed outright by a coating of oil (Hutchinson and Freedman 1975). Taller plants (which are not killed outright) often die later from premature loss of foliage; if a plant loses its leaves, it is unable to produce food and dies (Hutchinson and Freedman 1975). Vegetation that does survive a spill often has reduced growth.

Environmental conditions also affect plants' sensitivity to oil. For example, sensitivity is greatest on hot, sunny days when stomata are dilated, and diminishes during cold, cloudy weather when stomata are constricted. Sensitivity also depends on seasonal conditions; Hutchinson and Freedman (1975) noted that winter oil spills had a somewhat less severe impact on vegetation than did summer spills, because some plants are dornant in winter. However, when molecules are small enough to penetrate the leaf surface, sensitivity is determined more by plant anatomy than environmental conditions.

\section{EXTENT OF VEGETATION DAMIEGE}

The extent of vegetation damage from a spill would depend on the amount of oil spilled, time of year it was spilled, soil characteristics, topography, vegetation, $0 i 1$ viscosity, and reclamation practices employed. Of these, topography would be the most important factor because oil concentrates in depressions and disperses over flat areas.

Studies by Toogood et al. (1977) show that if no reclamation measures are taken where oil spills in an agricultural area, crop production is greatly reduced for up to five years (in soils with 2.5 percent oil by weight). After an application of oil resulting in 2 percent $0 i 1$ in soil by weight, Toogood et a1. found a 48 percent reduction in Canadian hay crops after three years. In Oklahoma soils, Plice (1948) found an initial 58 percent reduction in crop yields with an $0 i 1$ concentration of 1.0 percent by 
weight: crop production rose toward normal levels in years following this light oil application. (Figure 3 shows the probable time required to restore productivity of cropland following oil spills of different volumes.)

A study of natural revegetation of a spill in Canada found areas without vegatation three years after a light to moderate spill (Hutchinson and Freedman 1975). Rowell (1977) found that where oil spilled on sites without a seed source, vegetation was most successfully established if plants grew into the spill areas by extension of underground rhizomes.

Revegetation of forested areas after an oil spill would generally be more complex and difficult than revegtation of agricultural areas and grasslands. In some forested areas, soils are not well-developed and conditions are not conducive to microbiological degradation of $0 i 1$. In all types of vegetation, successful revegetation would depend on successful reclamation of soils.

\section{EFFECTS OF PIPELINE ABANDONMENT}

The effects of pipeline abandonment would be similar to those of pipe7 ine construction. Effects of flushing oil from pipe with water and treating discharge water would be much the same as the effects of hydrostatic testing and treatment of discharged hydrotest water, except wastes discharged from a flushed pipeline would contain some crude $0 i l$ wheras water discharged from hydrostatic testing would not.

If pipe from an abandoned line was salvaged, the right-of-way would be cleared again, the pipeline trench reexcavated, pipe removed, and the trench backfilled. This would require use of equipment similar to that used during construction; however, much more time could be taken to remove a pipeline than to construct it.

After pipe was removed, the disturbed land would be reclaimed. Reclamation after abandonment would differ from reclamation after construction in that there would be no need to control the growth of vegetation on a strip of land immediately above the pipeline trench; all the land disturbed by removal would be revegatated, including forested areas, which would be revegetated with trees.

\section{SUMMARY OF EFFECTS OF A PIPELINE SYSTEM ON SOILS AND VEGETATION}

In summary, the most significant, long-term impacts on soils from a large-diameter pipeline would result during construction from the mixing of soil horizons, compaction, and soil loss from erosion. These impacts would also affect the productivity and composition of vegetation.

Damage to vegetation resulting from a pipeline system would be shortterm to the extent that the vegetation cover and the land productivity on the construction right-of-way were restored. Long-term impacts would result where a pipeline was constructed through forested land (where regrowth of timber would be prevented for the life of a pipeline project) and where pump 
FIGURE 3. Probable time require to restore productivity of cropland following oil spills of different volumes.a
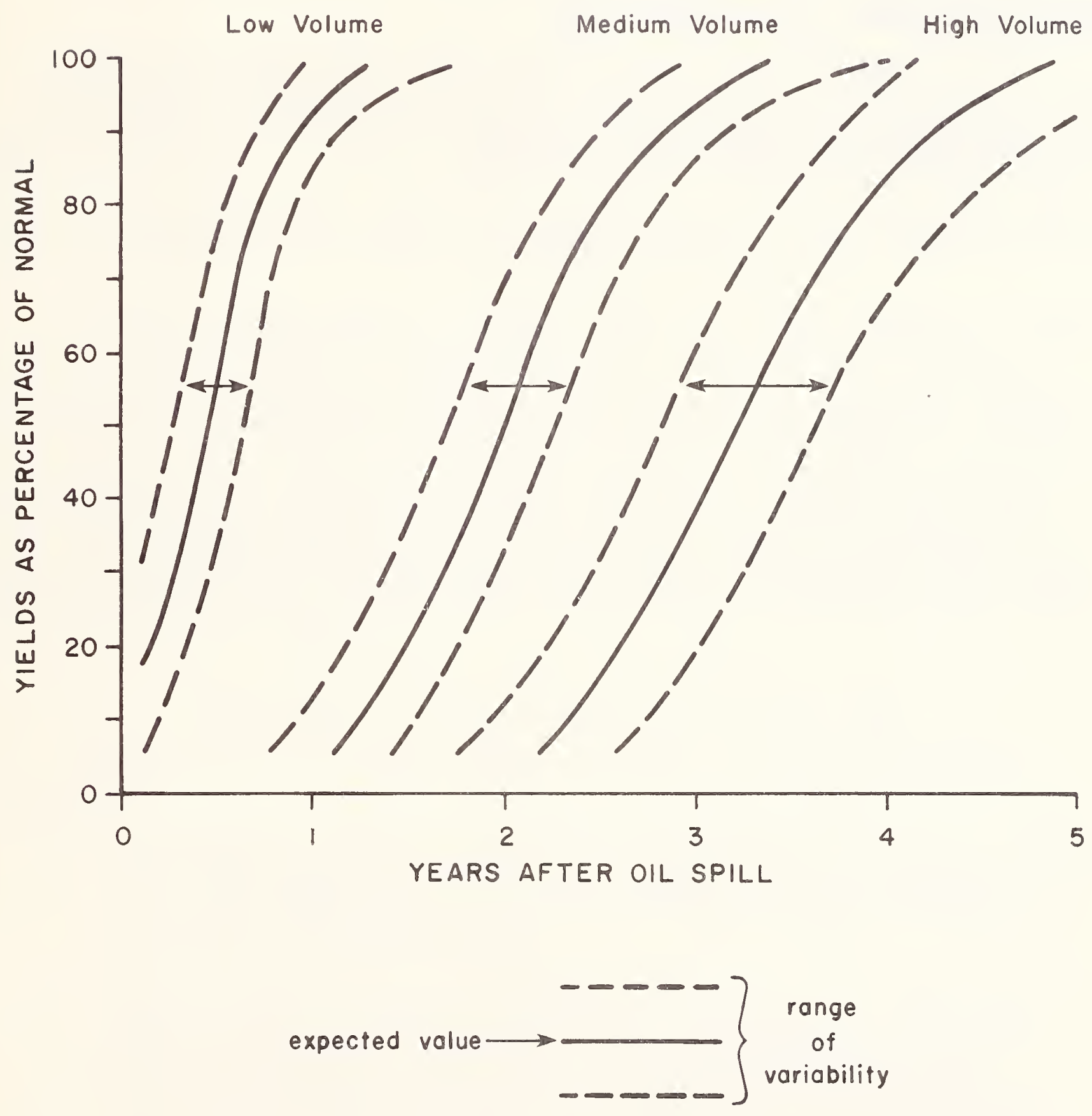

SOURCE: Derived from Toogood et a1. 1977.

NOTE: The assumption is made that crops are wheat, oats, and barley. aRestoration time would vary according to differences in the time of year oil spilled, soils, climate, management, and type of crop. 
stations or delivery facilities were constructed on forest land or cropland (where vegetation losses would be permanent). While these long-term effects could not be avoided, they could be mitigated by constructing and operating a pipeline with the narrowest possible rights-of-way or by establishing a centerline along existing, cleared rights-of-way.

The only irreversible or irretrievable vegetation losses that would result from a pipeline systen would be the loss of productivity on the permanent right-of-way during pipeline operation and the possible extinction of a rare plant species from right-of-way clearing. 


\section{CHAPTER FOUR}

\section{MITIOATING MEMSURES}

This chapter describes a range of measures that could be taken to reduce the severity of impacts on soils and vegetation from construction, operation, and maintenance of a pipeline system. The measures pertain onty to soils and vegetation; consequently, some may conflict with measures pertaining to other concerns, such as wildlife, aquatic life and habitats, land use, visual impacts, or pipeline engineering and economics.

To identify the measures that would provide the most effective mitigation of a project's overall impacts (not just its impacts on soils and vegetation), it would be necessary to examine all the possible mitigating measures for all concerns and assess the trade-offs among concerns. Several other factors would influence selection of mitigating measures: the laws, regulations, and policies governing pipeline siting, construction, operation, and maintenance; the statutory authority to ensure implementation of measures; and the cost-effectiveness of mitigation in specific situations. Thus, the mitigating measures for soils and vegetation that would be implemented for a particular project would probably not be identical to all those identified in this chapter.

\section{LOCATION OF A PIPELINE AND ASSOCIATED FACILITIES}

The potential for adverse impacts on soils and vegetation would be reduced by:

1) Locating the pipeline route and related facilities, such as access roads and pump stations, in areas where the risks of damage to soils and vegetation would be least.2 (See footnote on page 4 for a definition of access roads.)

2) Having a soils scientist, biologist, and reclamation specialist make an on-the-ground inspection of a proposed centerline and, wherever practical, modifying a proposed centerline and the location of associated facilities to avoid environmentally sensitive sites (sites where there would be a high risk of adversely affecting soils and vegetation). Environmentaliy sensitive sites include:

2 Methods of identifying areas where there would be a high risk of adversely affecting soils and vegetation are presented in appendixes $A$ ("Methods of identifying Areas of High Erosion Hazard") and B ("Methods of Identifying Areas of High Vegetation Impact Risk.") 
a) Steep or unstable slopes where extensive cut and fill would be required

b) Areas where soils are unstable

c) Areas with erosive or easily compacted soils

d) Habitats of threatened and endangered piant species

e) Fragile habitats, such as acid bogs, wetlands, thermal areas, and badlands

f) Areas with highly productive vegetation, such as forests or irrigated cropland

g) Areas that would be especially difficult to reclaim, such as high-elevation areas with a short growing season, areas where the soil and subsurface water have high concentrations of sodium salts or other salts, areas where soils have a high potential of shrinking and swelling, very steep slopes, and badiands

3) Mapping soils in areas where existing Soil Conservation Service information is inadequate for centerline evaluation. (This information would be useful for reclamation planning and $0 i 1$ spill cleanup, as well as centerline selection.)

4) Using soils information gathered during centerline evaluation to identify: (a) sites where topsoil should be segregated from subsoil during trenching and (b) the depth to which topsoil should be excavated.

5) During centerline evaluation, mapping and documenting in detail the environmentally sensitive sites that could not be avoided. (These areas could then be the focus of mitigative efforts during pipeline construction.)

\section{CONSTRUCTION PRACTICES}

\section{TIMING OF CONSTRUCTION ACTIVITIES}

by:

Damage from construction and maintenance activities would be mitigated

1) Avoiding construction and maintenance activities involving motorized travel at times when the soit is saturated with moisture, and when vehicle use would cause extensive ruts, channels, or wind erosion.

2) Minimizing the amount of time spent in areas where saturated soils must be crossed by motorized vehicles. 
SURVEYING AND STAKING

Adverse impacts of surveying and staking would be reduced by:

1) Preserving shrubs and trees to the greatest extent possible during surveying and staking.

2) Using hand methods to clear vegetation along survey lines.

\section{ACCESS ROADS}

Adverse impacts on soils and vegetation from pipeline access roads would be reduced by taking the following measures:

1) Limiting the number of new access roads to the minimum required to construct a pipeline system. This could be accomplished by using existing state, county, and other roads for access whenever possible. (See footnote on page 4 for a definition of access roads.)

2) Designing and building the necessary new construction access roads to serve as maintenance roads during pipeline operation.

3) Approving the location of all new roads before construction begins.

4) Clearly marking the location of access roads before equipment is moved to construction sites, and posting restrictions on the use of roads.

5) Designing roads to accommodate the largest piece of equipment that would be used and constructing roads no wider than would be necessary.

6) Constructing new roads with the minimum possible clearing and soil disturbance, and in a manner that would minimize erosion.

7) Constructing temporary roads on flat land (where it is available and where construction would be practical) to avoid damage from blading and grading.

8) Adequately maintaining roads while they are in use to avoid damage (for example, promptly filling ruts made by machinery to prevent channelling of runoff).

9) Using water, straw, wood chips, dust palliative, gravel, combinations of these materials, or similar materials to control erosion.

\section{MATERIAL SITES}

Damage to soils and vegetation at material sites would be mitigated if the following measures were taken:

1) Preparing a detailed plan for material sites (such as gravel pits). 
2) Excavating material sites so that their boundaries would blend with the natural lines of the surrounding landscape.

3) Avoiding the location of material sites in floodplains.

\section{CLEARING THE CONSTRUCTION RIGHT-OF-WAY}

Damage from the clearing of a construction right-of-way would be reduced by following these measures:

1) Clearing a construction right-of-way that is the minimum width necessary to allow construction to proceed expeditiously. (The second chapter of this report, "A General Description of Large, Undersround Crude-0il Pipelines," discusses factors that would influence the width of a construction right-of-way.)

2) Considering both environmental and engineering concerns when making decisions on right-of-way width. (While narrower rights-of-way would result in less damage to vegetation and soils, construction within a narrow right-of-way would be more difficult, costiy, and time consuming than construction within a wide right-of-way. Also, a very narrow right-of-way could impede revegetation because it might not allow room for segregation of topsoil and subsoil.)

3) Clearing vegetation selectively (wherever appropriate) to create irregularly shaped boundaries along the right-of-way, thus eliminating creation of a long, tunnel-like view along the right-of-way or access roads.

4) Using special techniques (such as hand clearing; to clear environmentally sensitive sites identified during centerline evaluation.

5) During right-of-way clearing, cutting all trees, snags, and other wood material so that they fall within the right-of-way and away from water courses.

6) Cutting all trees, snags, and other wood material removed during clearing so that stumps would be no higher than $15 \mathrm{~cm}$ ( 6 in), measured from ground-7evel on the uphill side of the stump.

7) Obtaining permission from the landowner or managing agency before cutting or damaging trees outside the right-of-way.

\section{TRENCHING}

Impacts of trenching would be reduced by separating topsoil from subsoil and storing the two separately, taking precautions to prevent wind and water erosion. 
Adverse impacts to soils and vegetation from motorized travel would be reduced by the following measures:

1) Avoiding construction activities involving motorized travel at times of the year when soil was saturated with moisture and when motorized travel would cause the formation of ruts and channels, or lead to significant wind erosion.

2) Minimizing the amount of time spent in areas where water-saturated soils would have to be crossed by motorized vehicles.

3) Avoiding motorized travel on, scarification of, or displacement of talus slopes, except where absolutely necessary.

4) Carrying out construction and operating vehicles in a manner that would minimize dust pollution.

5) Using materials other than oil or similar petroleum derivatives to control dust.

6) Hiring experienced personnel to operate earth-moving equipment.

7) Avoiding unauthorized cross-country travel and development of unauthorized roads during construction.

FIRE PREVENTION AND CONTROL

The following measures would reduce the risk of a fire or, in the event of a fire, reduce the damage to soils and vegetation:

1) Preparing a plan for preventing, controlling, and extinguishing fires on and near the right-of-way.

2) Monitoring construction to assure contractors carry out construction in a manner that complies with appropriate fire laws and regulations.

3) Properly storing and handling combustible material (for example, storing blasting caps and powder in containers and situating storage sites safe distances from one another).

4) Providing equipment necessary for fire protection and suppression. (For example, spark arresters and additional mufflers might be required on some vehicles in areas of high fire danger.)

5) Piling and windrowing burn material with tractors equipped with a forked clearing blade, and in a manner that would prevent destruction of vegetation and minimize erosion. 
6) Keeping burn piles small and compact to minimize the danger of forest and yrass fires.

DISPOSAL OF UEBRIS

These measures would mitigate adverse impacts from debris disposal:

1) Removing all debris from clearing and construction that might be carried into streams.

2) Disposing of all slash in the construction corridor and along access roads.

3) Burning slash and debris from construction only in approved locations, only during safe weather conditions, and in a manner that would meet state and local fire control standards.

MONITORING CONSTRUCTION

Adverse inipacts that could result from on-site construction decisions would be reduced if soils ard reclamation specialists and a biologist monitored construction to ensure consideration of soils and reclamation problems.

\section{RECLAMATION OF A CONSTRUCTION RIGHT-OF-WAY}

RECLAMATION PLAN

Uamage to soils and vegetation would be mitigated by preparing a reclamation plan:

1) besigned (to the greatest extent possible) to restore native vegetation and result in land uses and levels of productivity similar to those existing before pipeline construction.

2) Reflecting consideration of sites' geology, soils, native vegetation, precipitation, and topography.

3) Identifying the plant species, seed lilixtures, and seed sources that would be used in revegetation, along, with the season seed would be applied and equipment that would be used in seeding.

4) Providing for the posting of a bond that would be refunded upon successful revegetation. (See page 34 of this report for a discussion of how the success of revegetation could be measured according to percentage of plant cover.)

5) Identifyiny procedures for deternining reclamation success by measuring (on a statistical sampling basis) the percentage of plant cover along revegetated segments of a pipeline. 
Adverse impacts to soils and vegetation would be mitigated by:

1) Starting reclamation immediately after construction ended, with the goal of rapidly reestablishing ground cover on disturbed soils, consistent with the following measures.

2) Avoiding reclamation when soil moisture is high or the ground frozen.

3) Considering the use of irrigation in areas threatened by drought to promote initial reestablishment of vegetation.

4) Analyzing sites' seed requirements and seasonal precipitation patterns to identify planting dates in advance of pipeline construction.

5) Ordering seed and fertilizer at least one year in advance to avoid delays in reclamation.

6) Revegetating disturbed sites with native species wherever possible.

7) When construction ends at a time of year when seeds for native species could not be planted, using nonnative species that would not interfere with the establishment of native species (usually annuals) to temporarily revegetate a site and stabilize the soil, then reseeding the site with a combination of native grasses and shrubs at the appropriate time of year. (The amount of each species seeded would depend on soil characteristics, precipitation, elevation, and the type of cover desired.)

\section{RECLAMATION OF SLOPES}

Soil stability would be assured and surface water and runoff from reclaimed slopes controlled by reclaiming slopes to approximate natural land contours.

\section{RECLAMATION PROBLEM AREAS} areas:

These measure would help assure successful reclamation in difficult

1) Making a reclamation specialist (as well as the right-of-way agent) available to provide landowners advice on how to their land could be successfulty reclaimed.

2) Developing and using special techniques to reclaim the environmentally sensitive areas identified and mapped during centerline evaluation. 
The following measures would help assure successful revegetation:

1) Determining (on the basis of soil chemical and physical properties) the type of seed and the kind and amount of fertilizer and other soil amendments to be applied.

2) Using seed whose purity, germination success, and content of inert materials has been proven.

3) Using introduced species suited to a site's environment in areas (such as forests) where it would be necessary to remove original vegetation for the duration of a project and revegetate with grasses and shrubs.

4) Seeding areas of excessive soil erosion with native grass species to promote revegetation.

5) Near stream banks, where immediate stabilization would be required, planting shrubs in containers.

6) Using special techniques (such as drill seeding, hydroseeding, broadcast seeding with minimum use of mechanized equipment, and mulching with straw or woodchips) to encourage revegetation. (Aerial seeding should not be used because it does not assure distribution of the appropriate seed mixture on individual microenvironments.)

7) Covering seed and compacting soil after planting.

8) Temporarily controlling erosion with a variety of methods, including sediment traps, berms, slope drains, toeslope ditches, diversion channels, sodding, and mulching.

9) On rangeland, establishing cover that is 30 percent or more of the cover on adjacent range within a year of the beginning of revegetation, and 90 percent or more of that on adjacent range before reclamation is considered successful (except on certain sites identified during centerline evaluation).

10) Restocking forested 1and with trees (except land within the permanent right-of-way) and achieving a level of stocking that approximates that in adjacent areas before reclamation is considered successfut.

\section{MONITORING RECLAMATION AND REVEGETATION}

The following measures would help assure successful reclamation:

1) Inspecting revegetated portions of the right-of-way to evaluate reclamation success. 
2) Using the procedures identified in the reclamation plan to measure the percentage of plant cover at designated sites.

3) Regrading eroded surfaces and restoring original land contours where vegetation is not successfully reestablished, then reseeding or replanting areas and reemploying special erosion control techniques where necessary.

\section{PIPELINE OPERATION}

Impacts on soils and vegetation from operation of a pipeline system would be mitigated by:

1) In forested or shrub land areas, maintaining a cleared right-of-way the minimum width necessary to provide visibility for surveillance, and access for maintenance and oil spill cleanup equipment.

2) Preparing a plan for maintaining the permanent right-of-way, outlining clearing schedules and methods that would minimize vegetation damage.

3) Preparing a plan for preventing, controlling, and extinguishing fires within and near the permanent right-of-way.

4) Using mechanical methods, rather than herbicides, to prevent regrowth of trees and tall shrubs within a permanent right-of-way, unless mechanical methods would not successfully control regrowth.

5) Mechanically clearing only the minimum amount of vegetation necessary, and for only a short period in areas susceptible to damage from mechanical clearing.

6) Adopting an integrated weed control plan for right-of-way maintenance, including biological, mechanical, and herbicidal methods, where appropriate.

7) Where herbicides are used to control weeds, applying them by 1ocalized spraying rather than broadcast spraying.

8) If it would be necessary to apply herbicides, avoiding the use of persistent herbicides that could hinder reclamation efforts.

9) Timing maintenance inspections to ensure that maintenance would occur when access roads were firm, dry, or frozen, except in emergencies.

\section{OIL SPILLS}

\section{OIL SPILL CONTINGENCY PLAN}

Adverse impacts from oil spills would be mitigated by developing a contingency plan for controlling, containing, and cleaning up spill areas, 
with provisions for:

1) Controlling of oil spills.

2) Notifying the agency responsible for enforcing the plan.

3) Taking immediate action to contain the spill and restore the affected area to its original condition.

4) Approving materials or devices that would be used to control a spill, and techniques of handling oily substances.

5) Specifying techniques and schedules for revegetating forests, grasslands, agricultural lands, bottom lands, and wetlands, based on an area's soils, vegetation, precipitation, and other influential factors.

6) Identifying actions to be taken in the event of a break, leak, or explosion in the pipeline or related facilities.

7) Identifying emergency access routes for oil spill cleanup equipment that would (to the greatest extent possible) avoid wet areas, slopes over 10 percent, forests, compactable or erodible soils, areas subject to wind erosion, and watercourses.

CONTROL, CONTAINMENT, AND CLEANUP OF OIL SPILLS

Damage from oil spills would be reduced by:

1) Implementing the oil spill contingency plan.

2) Minimizing the size of cleanup worksites and the number and length of roads constructed to provide access for cleanup equipment.

3) Avoiding blading or grading where a temporary road for cleanup would cross flat land, unless it would be necessary to accommodate many large machines in a short period of time.

4) Flagging the location of unbladed roads.

5) Using helicopters to reach spills in environmentally sensitive areas or areas without access roads, if cleanup would not require the use of large machinery.

6) Providing a 30-m-wide (100-ft-wide) buffer zone along streambanks to protect waterways from a spill.

7) When time permits, constructing temporary bridges or earthen ramps to accommodate equipment where it would be necessary to cross a watercourse to control or clean up a spill, then removing bridges or ramps when the spill had been cleaned up. 
8) Constructing sediment retention basins where sediment from cleanup operations or access roads endangered the quality of nearby waterways.

9) Avoiding blasting, the use of streambed materials for spill control structures, and operation of heavy equipment in streams, unless the activities would be necessary to prevent environmental damage more severe than that caused by the spill itself.

10) Having scientists qualified to judge the relative severity of impacts of blasting, use of streambed material, and operation of heavy equipment in streams approve their use.

11) Consulting with appropriate agencies before excavating for fill or riprap to contain a spill.

12) Removing litter and debris (such as garbage and chemicals) from a spill area after the spill was contained and contaminated soil removed, and restoring the area to as natural a condition as possible.

13) Repeating a cleanup operation to remove additional debris that appeared in months or years following a spill.

\section{RECLAMATION FOLLOWING A MAJOR OIL SPILL}

\section{RECLAMATION PRACTICES}

The long-term effects of an oil spill would be mitigated with the following reclamation measures:

1) Designing reclamation to restore an area's original vegetation and land use.

2) Reclaiming agricultural areas and grasslands using the following methods that Toogood et al. (1977) found to be successful:

a) Determining the soil type of the spill area by sampling both contaminated and uncontaminated soil to a depth of $30 \mathrm{~cm}(12$ in), and analyzing for nutrients and oil content

b) Testing the soil to determine the amount and kind of fertilizer needed, applying fertilizer with a broadcast spreader, and mixing the fertilizer into the contaminated soil

c) Testing contaminated soils periodically, depending on precipitation and temperature (which influence the rate at which oil is broken down by microbial activity)

d) Revegetating a site when analyses indicate the oil content of the soil had stabilized and the demand for nutrients decreased 
e) Testing the nitrate content of crops to prevent the consumption of excessive amounts of nitrates by humans and animals

f) Monitoring spill areas continuously to determine the success of revegetation

g) Refertilizing and reseeding areas where reclamation was not successful, placing sod on sites where seeding would be difficult

3) Planting wheat or oats on agricultural lands initially (because these crops can tolerate oil-contaminated soil) and planting with arother crop, if desired, after the land is successfully revegetated with the initial crop (Toogood et al. 1977).

4) Revejetating grasslands in a manner similar to the way in which a construction right-of-way would be revegetated: first seeding with a rapidly growing annual for temporary erosion control, then with species simila to those growing on land adjacent to the spill (Toogood et a7. 1977).

5) Using revegetation methods similar to those found successful on agricultural and grasslands to revegetate forested $0 i 1$ spill areas (Toogood et al. 1977).

6) Using native plants that have grown successfully on forested sites where $0 i 1$ has spilled to revegetate forested spill areas (see table 1).

7) Placing a black plastic film over spills occurring in cool weather to increase soil temperature and speed breakdown of $0 i 1$ by microbial activity.

8) Assuring an adequate nutrient supply after a spill by applying fertilizer to establish a 10:1 or 15:1 C:N ratio (Gudin and Syratt $1975)$.

\section{MONITORING RECLAMATION}

Damage would be further reduced by:

1) Monitoring all reclamation to ensure:

a) Replacement of topsoil removed during spill control, or damaged - by oil or a fire

b) Rapid establishment of vegetative cover

c) Reclamation of access roads and work sites

d) Recontouring or filling of excavations 
TABLE 1. Plants recommended for use in reclaiming forested oil spill areas

\begin{tabular}{|c|c|c|}
\hline Family & Genus and Species & Common Name \\
\hline Compositae & $\begin{array}{l}\frac{\text { Bidens }}{\text { Senecio }} \frac{\text { cernua }}{\text { spp. }} \\
\frac{\text { Solidago }}{\text { Sonchus }} \frac{\text { lepida }}{\text { spp. }}\end{array}$ & $\begin{array}{l}\text { Beggar-ticks } \\
\text { Ragwort } \\
\text { Goldenrod } \\
\text { Sow-thistle }\end{array}$ \\
\hline Cornaceae & Cornus canadensis & Bunchberry \\
\hline Cyperaceae & $\begin{array}{l}\text { Carex aquatilis } \\
\text { Eriophorum chamissonis }\end{array}$ & $\begin{array}{l}\text { Sedge } \\
\text { Cotton-grass }\end{array}$ \\
\hline Equisetaceae & Equisetum & Horsetail \\
\hline Ericaceae & Vaccinum spp. & Huck leberry \\
\hline Graminae & $\begin{array}{l}\text { Agrostis spp. } \\
\text { Agropyron smithii } \\
\text { Festuca spp. } \\
\text { Hordeum spp. } \\
\text { Phalaris arundinacea }\end{array}$ & $\begin{array}{l}\text { Bentgrass } \\
\text { Western wheatgrass } \\
\text { Fescue } \\
\text { Barley } \\
\text { Reed canarygrass }\end{array}$ \\
\hline Juncaceae & Juncus spp. & Rush \\
\hline Labiatae & Galeopsis tetrahit & Hemp nettle \\
\hline Leguminoseae & Melilotus alba & Sweet-clover \\
\hline Menyanthaceae & Menyanthis trifoliata & Buckbean \\
\hline Onagraceae & Epilobium angustisolium & Fireweed \\
\hline Ranunculaceae & Ranunculus spp. & Buttercup \\
\hline Rubiaceae & Galium boreale & Northern bedstraw \\
\hline Salicaceae & Salix spp. & Wi1low \\
\hline Saxifragaceae & Heuchera spp. & Al umroot \\
\hline Unbelliferae & Sanicula spp. & Snake-root \\
\hline
\end{tabular}

SOURCE: MCGill and Nyborg 1975. 
e) The use of special erosion-control techniques, such as mulching, if standard reclamation procedures fail

f) Reestablishment of damaged stream channels, banks, bottom gradients, and sediments

g) Reclamation of cultivated soils compacted by equipment

2) Evaluating the success of reclamation of forested lands according to the following criteria developed by McGill and Nyborg (1975):

a) Plants' nutrient requirements must be met

b) Soil pH, salt content, aeration, and water supply must correspond to plants' requirements

c) A viable seed source or root stock (either native or introduced) must be available

d) There must be no toxic materials in soil 


\section{APPENDIX $\triangle$}

\section{METHODS OF IDENTUFYING AREAS OF HIGH EROSION MAZARD}

During the planning and construction of a large-diameter pipeline, soils information is needed in order to make yeneralized comparisons of the potential for soil erosion along alternative pipeline routes. There is no need to conduct thorough studies of soils for all alternate routes if a fast and inexpensive method is available for identifying major soil erosion problems. Such a method should, to a large extent, make use of existing information, perhaps supplemented by spot checks of soils along the alternate routes.

Moder soil studies (those done during approximately the past ten years) are available for many, but not all, Montana counties. These studies provide information that is adequate for making generalized comparisons of routes. For areas without modern soil surveys, a rapid and inexpensive evaluation of potential soil erosion problems can be made using existing maps of substrate geology (parent material), climate, and slope steepness, which are major determinants of soil erosion rates.

Ideally, information on soil texture, structure, and chemistry should also be used in the evaluation, but this information is generally lacking for areas where no modern soil surveys have been done; a rough estimate can be drawn from substrate information. Slope length is another important determinant of the rate of soil erosion, but it is impossible to determine slope length from small-scale maps, which are frequently all that are available for displaying alternate route segments for study and comparison.

Because of their importance in estimating probable erosion rates, climate, slope steepness and lenyth, and substrate are discussed in more detail below.

\section{CLIMATE}

The climatic factors relevant to erosion hazard are precipitation (generally measured in in/yr) and the number of days in the frost-free season.

\section{Precipitation}

The average annual precipitation of an area is a rough indicator of the potential for erosion and sediment transport, raindrop inpact, surface runoff from rainstorms, and snow-melt. These precipitation impacts would be major factors in erosion hazard because for months or even several years after pipeline construction, the right-of-way would have little vegetation cover 
to retard erosion. Erosion resulting frolil precipitation could be prevented to some extent by employing special reclamation procedures, such as mulching. Special procedures are expensive, but would be highly desirable in areas with a high erosion potential. Average annual precipitation ranges could be based on Soil Conservation Service (SCS) units (Ross and Hunter 1976).

\section{Length of the Frost-Free Season}

The length of the frost-free season (see, for example, Southard 1973) is a measure of the probable rate and eventual success of revegatation of the cleared construction right-of-way. Grasses and herbs would root and grow slower and with less success in cold areas (those with short frost-free seasons) than in warm areas; thus it would be more difficult to stabilize soils in cold areas than in warm areas. In order to assign "worst case" erosion potential values to frost-free season length ranges, the highest erosion potential may be designated as less than 50 days, and the lowest erosion potential as greater than 130 days.

The precise relation (if there is a relation) between length of the frost-free season and precipitation is not known; for comparative purposes, the tivo variables may be assurned to be equal in importance.

\section{SLOPE STEEPNESS AND LENGTH}

Percent slope ranges can be measured with templates showing contour spacing for slope ranges at a particular map scale and contour interval (USDA 1962).

For rough comparisons of sites along routes, it may be assumed that erosion hazard along a pipeline right-of-way would be proportional to the slope percerit, and to the two climate parameters mentioned above. However, erosion rates may be high on nearly level terrain; for example, even on 0 to 3 percent slopes, significant amounts of soil could be lost from sheet erosion (Crowley 1978). Soil losses from sheet erosion on low slopes would not be as obvious as losses from rill and yully erosion.

Erosion hazard increases greatly with increasing slope length because runoff velocities increase exponentially with increased length of slope. slope length information should be used primarily for centerline and sitespecific studies because most short slopes cannot be measured on small-scale maps.

\section{SUBSTRATE}

For areas where detailed information on soil texture, structure, and chemistry is not available, information on geologic parent material may be substituted and compared with information on parent material available from soil surveys. Each of the parent materials mapped could be assigned a value reflecting the relative erosion potential; table 2 indicates the erosion potential of various parent materials commonly found in Montana. Some parent 
materials, such as interbedded sedimentary rocks, alluvium, and undifferentiated sedimentary rocks, are impossible to characterize in terms of erosion potential; it would be best to base erosion potential for such areas on climate, slope, and slope length.

TABLE 2. Erosion potential of various parent material common in Montana.

Parent Material

Undifferentiated

or interbedded

alluvium, glacial

till, and alluvium

Till

Sandstone, quartzite, limestone, dolomite, granite, gneiss, and schist

Marine and non-marine siltstone and shale, argillite and siltite, lake sediments, and volcanics
Erosion Potential

Cannot be characterized

Moderate

Moderate to high

High

Soils formed from these parent materials are rich in clay and silt, easily compacted and eroded when water-saturated, and eroded relatively easily by wind and water when dry. 
. 


\section{METHODS OF IDENTIFVING AREAS OF HIGH VEGETATION IMPACT RISK}

The most favorable pipeline route, from the standpoint of vegetation, could be identified by comparing the following characteristics of alternative routes: (1) potential to produce timber, livestock forage, and crops and (2) ability to recover from disturbance. (These characteristics indicate only the utilitarian values of vegetation; comparative data based on ecological values, such as species diversity and primary productivity, generally are not available.)

\section{PRODUCTIVE POTENTIAL OF VEGETATION}

Productivity is based on site quality--the total of all the factors influencing an area's ability to produce vegetation. Current productivity is influenced by many variables that are subject to rapid change; because pipeline rights-of-way would require use of land for many years, potential, rather than existing, productivity should be used to assess productivity.

Timber productivity may be rated based on average timber growth, medsured in $\mathrm{ft}^{3} / \mathrm{acre} / \mathrm{yr}$ (Pfister et a1. 1977). Livestock forage productivity may be rated on the basis of animal unit months, air-dry pounds of forage produced/acre/yr, or grass constancy and average coverage (Ross and Hunter 1976, Pfister et a1. 1977, Davis 1974). The cumulative timber and range productivity for each habitat type can be calculated by adding the two ratings. Cropland productivity can be measured in terms of average crop yield/acre.

\section{RATES OF RECOVERY FROM DISTURBANCE}

Vegetation impact risk can also be comparatively estimated in terms of the amount of time it would take for different vegetation types to reestablish in disturbed areas. Restoration time can be used to determine relative impacts on vegetation because it indicates the duration of impacts.

Any alteration in the composition and dynamics of plant communities results in population changes of flora and fauna inhabiting an area. Each vegetation type occurs with a unique association of plants and arimals having varying tolerarice of disturbance; the plant association that reestablishes itself slowly after disturbance would be damaged more than an association that recovers rapidly. Thus, the kind and degree of impacts on vegetation vary according to vegetation type, and can be accurately evaluated only in reference to specific sites. 


$$
\text { , }
$$


acid bog--A heavily veyetated wetland lacking a solid foundation, and having a pH below 6.6. Commonly found in and along lakes and potholes.

adsorption--The adhesion of loosely bonded molecules or ions on the surface of a solid.

alkaline soil--A soil whose $\mathrm{pH}$ is higher than 7.0 .

base exchange colloids--See cation-exchange capacity.

bentonite--A soft, porous, rock consisting of colloidal silica and clay minerals (mainly of the montmorillonite group).

berm--An embankment of fil1.

carbon-nitrogen ratio--A ratio that is obtained by dividing the percentage of organic carbon by the percentage of total nitrogen in a soil.

cations--An atom or group of atoms that is positively charged because of the loss of one or more electrons.

cation exchange--The interchange between a cation in solution and another cation on the surface or interior of material such as organic colloids or clay mineral.

cation exchange capacity--The total of exchangeable cations that a soil, a clay mineral, or other substance can absorb.

centerline--The precise location of the linear center of a pipeline right-ofway, as surveyed and staked on the groind.

colloid--A collection of fine-grained submicroscopic particles with a size range of approximately $10^{-3}$ to $10^{-6} \mathrm{~mm}$, having a large surface area per unit of mass, and often displaying the ability to remain suspended in a material.

easement--A legal agreement in which a landowner grants the pipeline company the authority to carry on certain pipeline-related activities within a specified area.

construction easement--A legal agreement in which the landowner grants the pipeline company authority to carry out all activities necessary to install the pipeline. Usually granted for a wider parcel of land than the construction right-of-way. 
permanent easement--A legal agreement in which the landowner grants the pipeline company authority to carry out pipeline operation and maintenance activities on the land in proximity to the pipeline. Usually granted for a wider parcel of land than the permanent right-of-way.

eminent domain--A government's right to take, or authorize the taking of privately owned land for a public use. The owner is compensated.

erosion--The process whereby earth materials are loosened or dissolved and removed from a part of the earti's surface by running water, waves, ice, or wind.

fee ownership--A legal ayreement that provides total ownership of land with unrestricted rights to use the land; the ownership is granted in perpetuity.

hydrostatic test--The applicalion of a predetemined fluid pressure to the interior of a pipe to test its ability to withstand a specified test pressure over a prescribed time period.

large-diameter pipeline--li pipeline over $76 \mathrm{~cm}$ (30 in) in diameter.

permeability--The ease of penetration of soil by 1 iquids.

pH--The degree of acidity or alkalinity of a solution.

phenological response--The cyclical behavior of an organism's time of

flowering, leafing, and so forth, in relation to the climate, or a response to a disruption of climatic conditions.

pore--Any smail passage or cavity in a soil or rock.

porosity-m. The volume of pore space in a solid substance.

rhizorne--An underyround stem that stores food.

right-of-way--The strip of land appropriated by a pipeline company through easement, condeinnation, or fee ownership.

construction right-of-way--The strip of land, appropriated by a pipeline company, that is actually disturbed during construction of a pipeline; usually larger than the perilanent right-of-way.

permanent right-of-way--The strip of land, appropriated by a pipeline company to accommodate maintenance activities during operation of the pipeline; usually narrower than the construction right-of-way.

riprap--Blocks of rock, coninonly of irregular shape, used to armor parts of streambanks, shorelines, or artificial embankments against erosion.

route--The general location of a pipeline right-of-way, subject to adjustments of $1.6 \mathrm{~km}$ ( $1 \mathrm{mi}$ ) or more during centerline location. 
saline soil--Soil containing soluble salts, which may retard plant growth; soil having a low exchangeable-sodiun capacity.

shale--Fine-grained, sedinentary rock formed by the consolidation of clay, silt, or mud; splits into thin layers if broken.

shear--Deformation of a substance under stress; adjacent areas are displaced in opposite directions parallel to each other.

slash--Tree limbs or brush cut down to clear the right-of-way.

soil horizon--A layer of soil that is distinguishable from adjacent layers by characteristic physical properties such as structure, color or texture or by chemical composition.

stomata--Pores in the epidermis of a plant through which gases are exchanged.

talus slopes--Fragments of rock accumulated at the foot of cliffs or on steep slopes.

topography--Surface features of the earth, such as hills, lakes, and valleys. xerophytes--Plants that grow in extremely dry soils--such as cactus. 
. 


\section{LITERATURE CITIRD}

Branson, F. Miller, R. and McQueen, I. 1970. Plant communities and associated soil and water factors on shale-derived soils in Northeastern, Montana. Ecol. 51(3):391-407.

- Miller, R. ana McQueen, I. 1966. Contour furrowing, pitting, ripping on rangelands of Western united States. U. Ran. Mgmt. $19: 182-190$.

Erown, R. 1971. Distribution of plant communities in southeastern Montana Badlands. Amer. Midland Nat. 85(2):458-477.

Carvel1, k. 1976. Effects of herbicidal management of electric transmission line rights-of-way on plant communities. In: Proc. of First Nat. Sympos. on Erivir. Concerns in Rights-of-Way Mgnt. Miss. State Univ. $335 \mathrm{p}$.

Chappel1, W., Coartney, J. and Will, J. 1976. The use of plant growth regulators in rights-of-way maintenance. In: Proc. of First Nat. Sympos. on Envir. Concerns in Rights-of-Way Mgmt. Miss. State Univ. $335 \mathrm{p}$.

Crabtree, A. F., Bassett, C. E. and Fisher., L. E. 1973. The impacts of pipeline construction on stream and wetland environments. Michigan Public Service Commission, Lansing, Michigan. 115 p.

Crowley, C. 1978. Soil conservation: Soil conservation, 43 (6):4-7.

Currier, H. E. 1951. Herbicidal properties of benzene and certain Methyl derivatives. Hilgardia. 20:383-406.

Davis, Carl. 1974. A guide for determining potential herbage productivity of Central Montana range areas and potential range areas. U.S. Dept. of Agriculture, Forest Service. GaTlatin National Forest, Bozeman, Montana. Review draft.

t11 is, R. and Adams, R. 1961. Contamination of soils by petroleum hydrocarbons: Advarices in Agronomy. 15:197-216.

Evans, R. and Young, J. 1977. Weed control - revegetation systems for big sagebrush - Downy Brome Rangelands. J. Ran. Migmt. 30(5):331-336.

Gudin, C. and Syratt, W. 1975. Biological aspects of land rehabilitation following hydrocarbon contamination. Envir. Pollut. 8:107-112. 
Hanson, H. T., and Whitman, W. C. 1943. Plant succession on soloretz soils in western North Uakota. Ecology. (18)516-522.

Hemmer, L. Johnson, So and Beck, R. 1977. Bentorite mining related reclamation problems. Mont Lept. of State Lands, Helena, Montana. 94 p.

Hughes, W. 1976. Section Z NCR, July 20-25. Joint Fish and Wildlife Advisory Team. Anchorage, Alaska.

Hutchinson, T. C. and Freednian, W. 1975. Effects of experimental crude $0 i 1$ on tiaga and tundra vegetation of the Canadian Arctic. In: Conference on prevention and Control of $0 i 1$ Pollution (Proceedings). American Petroleum Institute, pp. 517-525.

Kulkarni, B. and Savant, N. 1977. Effect of soil compaction on root-cation exchange capacity of crop plants. Plant and Soil. 48(2):269-279.

Leonard, 0. A. and Harris, V. C. 195:́. The effect of aliphatic hydrocarbons on the hypocotyls of cotton and soybeans and on the shoots of nutgrass, Johnson grass, and other weeds by the Directional Spray Technique. Weeds. 1:256-273.

L." n, J. and Mueggier, w. 1968. Herbicide treatmerit of north Idaho browse evaluated six years later. J. Wildlife figmt. 32(3):538-541.

Mackay, J.E. and Mohtadi, M. 1975. The area affected by oil spills on land. Canadian Jour. of Chemical Engineering. V. 53.

MCGi11, W. and Nyborg, M. 1975. Reclamation of wet forest soils subjected to $0 i 1$ spills. Alberta Institute of Pedology Pub. no. G 74-1, Edmonton, Alberta, 129 .

Minshall, W. H. and Helson, V. A. 1949. The rerbicidal action of oils. Proc. Amer. Soc. Hort. Sci. 53:294-298.

Nelson-Snith, A. 1968. The effects of oil pollution and eniulsifier cleansing on shore life in south-west Éritain. J. Appl. Ecol. 5:97-107.

Northern Tier Pipeline Company, 1978. Northern Tier Pipeline project description of the proposed action. Submitted to the Bureau of Land Management of the USDI. May 12, 1978.

Payne. (No date). The Effect of 2, 4-D on Sagebrush and Associated Vegetation on the Beaverhead National Forest, Montana. Mont. Agric. Expt. Stat.

Pfister, R.D., Kovalchik, B.L., Arno, S.F. and Presby, R.C. 1977. Forest Habitat Types of Montana. U.S. Uept. of Agriculture, Forest Service. Gen. Tech. Report INT-34. Ogden, Utah.

Plice, M.J. 1948. Sonie effects of crude petroleum on soil fertility. Proc. Soij Sci. Soc. Ami. 13:413-416. 
Raghaven, G., Mckyes, E., Stemshom, E., Ciray, A. and Beaulieu, B. 1977. Vehicle compaction patterns in clay soil. Trans. of the Am. Soc. Ag. Engs. $20(2): 218-219$.

Rasmussen, L.W. 1947. The physiological action of 2-4-dichloro phenoxyacetic acid on dandelion, Taraxacun officinale. Plant Physiol. $22: 377-392$.

Rieh1, L.A., R.T. Wedding, LaDue, J.P. and Rodriguez, J.L. 1958. Effect of a California spray oil on transpiration of citrus. J. Econ. Entonol. $51: 317-320$.

Ross, R.L. and Hunter, H.E. 1976. Climax veyetation of Montana based on soils and climate. U.S. Lept. of Agriculture, Soil Conservation Service, bozeman, Montana. 64 pp.

Rowe11, M. 1977. The effect of crude oil spills on soils - a review of literature. In The reclamation of agricultural soils after spilis Part 1: Research, ed. Toogood, J. Department of Soil Science, University of Alberta, Edmonton, Alberta. 140 pp.

Ryker, R. 1966. Herbicides fail to insure success of a brushfield prescribed burn. USDA Forest Service Res. Note INT-55.

- 1970. Effects of dicamba and picloram on some Northern Idaho shrubs and trees. USDA Forest Service Res. Note INT-N4. Ogden, Utah.

Soiseth, R., Wight, J. and Aase, J. 1974. Improvement of panspot (solonetzic) range sites by contour furrowing. J. Rang. Mgmt. $27(2): 107-110$

Southard, A. 1973. Soils in Montana. Montana Agricultural Exp. Sta. Bull. $621,42 \mathrm{pp}$.

Toogood, J.A., Rowel1, M.J. and Nyborg, M. 1977. Reclamation experiments on the field. In The reclamation of agricultural soils after oil spills, Part 1: Kesearch, ed. J.A. Toogood, A.I.P. Pub7. No. M-77-11. pp. 34-64.

U.S. Department of Agriculture, Soit Survey Staff. 1962. Soil Survey Manual. U.S. Uept. of Agriculture Handbook no. 18. U.S. Government Printing Office, Washington, D.C.. 503 pp.

U.S. Department of Interior, Bureau of Land Management. 1979. Draft enviromental impact statement, crude $0 i 1$ Transportation System: Port Angeles, washington to Clearbrook, Minnesota (as proposed by NTPC).

Vanoverbeek, J. and B Tondeau, R. 1954. Mode of action of phytotoxic oits. Weeds. $3: 55-65$.

Voorhees, w. 1977. Soil Compaction. Crops and Soils. 29(4):13-15 Vories, K.C. 1976. Reclamation of Western Surface Mined Lands (Workshop Proceedings). Ecology Consultants, Inc. $152 \mathrm{pp}$. 
White, E. and Lewis, J. 1969. Ecological effect of a clay soil's structure on some native yrass roots. J. Rng. Migmt. 22(6):401-404. 

$$
\text { . }
$$ 



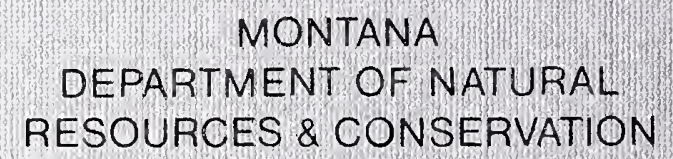

Helena Montana

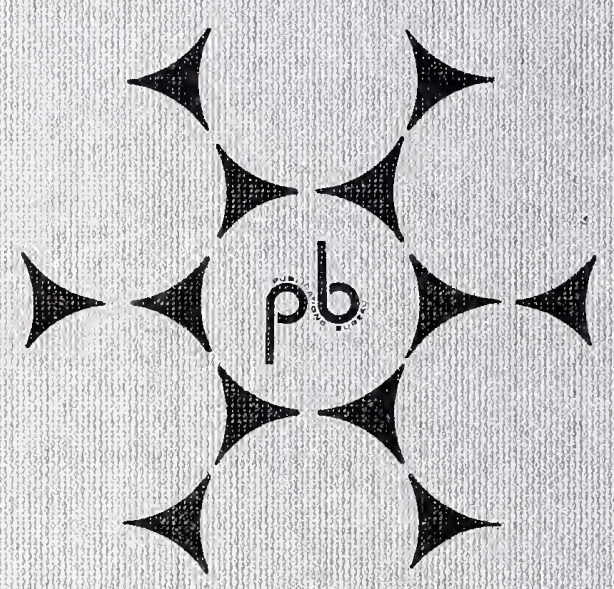

200 copies of this public document were published at AN ESTIMATED cost of $\$ 2.09$ per copy for a total cost of $\$ 418.80$ which includes $\$ 234.80$ for printing and $\$ 184.00$ for distribution. 